\title{
KONSEP PERSATUAN DENGAN KEMATIAN DAN KEBANGKITAN KRISTUS BERDASARKAN ROMA 6:1-14
}

\author{
Hanny Frederik ${ }^{1)^{*}}$ \\ ${ }^{1)}$ Mahasiswa Program Pascasarjana Prodi Teologi Sekolah Tinggi Theologia Jaffray \\ ${ }^{*}$ Penulis korespondensi: hannyfrederik@yahoo.com
}

\begin{abstract}
Abstrak
Persatuan orang percaya dengan Kristus adalah doktrin yang merupakan pemikiran kunci dalam ajaran Tuhan bahkan sangat penting bagi teologi Paulus sehingga seorang penafsir, James S. Stewart menyebutnya sebagai "inti dari agama Paulus." Menurut hasil uraian tentang konsep persatuan dengan kematian dan kebangkitan Kristus berdasarkan Roma 6:1-14, maka penulis menarik beberapa kesimpulan sebagai berikut: Pertama, orang percaya telah dipersatukan dengan kematian dan kebangkitan Kristus melalui baptisan, yang berarti ia turut serta mengalami peristiwa-peristiwa yang dialami oleh Kristus dalam sejarah, yakni penyaliban, kematian, penguburan dan kebangkitan Kristus. Kedua, persatuan dengan kematian dan kebangkitan Kristus mengakibatkan berlalunya ciptaan lama, yaitu kematian manusia lama sebagai status atau kedudukan seseorang dalam persekutuannya dengan Adam. Kematian Kristus adalah kematian bagi dosa, karena itu dalam persatuan dengan kematian Kristus, orang percaya juga telah mati bagi dosa. Ketiga, persatuan dengan kematian dan kebangkitan Kristus menghasilkan ciptaan baru, yaitu kehidupan baru sebagai status atau kedudukan orang percaya dalam persekutuan dengan Kristus. Keempat, kehidupan yang berpadanan dengan status baru orang percaya dalam Kristus adalah kehidupan dalam pengudusan yang meliputi hidup dalam pertobatan dan hidup untuk melayani Allah.
\end{abstract}

Kata-kata kunci: persatuan, kematian, kebangkitan, Kristus, Roma 6:1-14

The unity of the believer with Christ is a doctrine which is a key thought in the teaching of Jesus, moreover it is very important for Paul's theology such that one commentator, James S. Stewart, delineates it as the "Man in Christ: The Vital Elements of St. Paul's Religion." Based upon the results of an analysis about the concept of unity in the death and resurrection of Christ based upon Romans 6: 1-14, the author draws several conclusions as follows: First, believers have been made one with the death and resurrection of Christ through baptism, which means the believer participates in the events which were historically experienced by Christ, that is, the crucifixion, death, burial, and resurrection of Christ. Second, unity with the death and resurrection of Christ causes the passing of the old creation; the death of the old man as the status or position of a person regarding their relationship to Adam. The death of Christ is a death to sin, because in the unity with the death of Christ, a believer has also died to sin. 
Third, unity with the death and resurrection of Christ produces a new creation, that is, a new life, with the status or position of a believer regarding their relationship to Christ. Fourth, a life which is in harmony with the new status of a believer in Christ is a life in the process of sanctification, which encompasses living in repentance and living to serve God.

Keywords: unity, death, resurrection, Christ, Romans 6:1-14

\section{Pendahuluan}

Persatuan orang percaya dengan Kristus adalah doktrin yang merupakan pemikiran kunci dalam ajaran Tuhan bahkan sangat penting bagi teologi Paulus sehingga seorang penafsir, James S. Stewart menyebutnya sebagai "inti dari agama Paulus," sebagaimana dikutip oleh Boice dalam bukunya yaitu Dasar-Dasar Iman Kristen. ' Bagi Paulus, persatuan dengan Kristus bisa berarti orang percaya berada di dalam Kristus dan Kristus berada di dalam diri orang percaya. "Jadi siapa yang ada di dalam Kristus ia adalah ciptaan baru: yang lama sudah berlalu, sesungguhnya yang baru sudah datang" (2 Kor. 5:17) dan "Aku telah disalibkan dengan Kristus; namun aku hidup, tetapi bukan lagi aku sendiri yang hidup, melainkan Kristus yang hidup di dalam aku. Dan hidupku yang kuhidupi sekarang di dalam daging, adalah hidup oleh iman dalam Anak Allah yang telah mengasihi aku dan menyerahkan diriNya untuk Aku" (Gal. 2:19-20). Ini adalah ekspresi dari kedekatan Tuhan dengan orang percaya yang merupakan salah satu dari "misteri-misteri" besar yang telah dinyatakan dalam Injil dan diberitahukan oleh Allah hanya melalui penyataan (wahyu). ${ }^{2}$

Salah satu pikiran Paulus tentang persatuan dengan Kristus tertuang dalam suratnya kepada jemaat di Roma. Melalui Roma 6:1-14, Paulus menjelaskan konsep pemikirannya tentang persatuan orang percaya dengan kematian dan kebangkitan Kristus. Paulus menguraikannya sebagai dasar dari pernyataannya, "Kita telah mati bagi dosa” (Rm. 6:2). Karena orang percaya telah mati bagi dosa, maka ia tidak boleh hidup bertekun di dalam dosa. Paulus harus menjelaskan hal ini karena selalu ada interpretasi yang salah terhadap pengajarannya tentang pembenaran sebagai anugerah Allah secara cuma-cuma yang dapat diterima hanya oleh iman, bukan berdasarkan perbuatan manusia. Secara khusus juga terhadap pernyataannya di akhir Roma pasal 5 bahwa di mana dosa bertambah banyak di situ kasih karunia Allah berlimpah-limpah (Rm. 5:20-21). Seseorang mungkin berkata, "Jika

\footnotetext{
lJames Montgomery Boice, Dasar-Dasar Iman Kristen (Surabaya: Momentum, 2011), 441.

${ }^{2}$ Sinclair B. Ferguson, Kehidupan Kristen: Sebuah Pengantar Doktrinal (Surabaya: Momentum, 2011), 138.
} 
pembenaran tidak berdasarkan perbuatan manusia dan kasih karunia Allah akan berlimpah-limpah ketika dosa bertambah banyak, maka baiklah kita terus berbuat dosa agar kasih karunia Allah semakin berlimpah."

Sebelum menulis surat kepada jemaat di Roma, rasul Paulus dalam pelayanannya pernah menghadapi hal ini. Jemaat Korintus hidup dalam moralitas yang sangat longgar. Paulus menyikapinya dengan memperingatkan mereka bahwa mereka telah dipersatukan dengan Kristus, bukan hanya dari segi roh mereka, melainkan seluruh keberadaan mereka. ${ }^{3}$ Paulus menegaskan, "Tidak tahukah kamu, bahwa tubuhmu adalah anggota Kristus?" (1 Kor. 6:15). Karena itu, orang percaya harus meninggalkan dosa dan hidup menurut keadaan mereka yang baru yang telah dipersatukan dengan Kristus. Ladd menyatakan bahwa karena adanya fakta-fakta penebusan tertentu, maka ada pula akibat-akibat tertentu yang tak dapat dihindari. Aku telah dipersatukan dengan Kristus, karena itu aku harus hidup menurut cara tertentu. ${ }^{4}$ Kepada jemaat di Galatia, Paulus juga menegaskan bahwa orang percaya telah mengenakan Kristus (Gal. 3:27) dan telah dimerdekakan oleh Kristus (Gal. 5:1). Tetapi kemerdekaan itu jangan dipakai sebagai kesempatan untuk kehidupan dalam dosa, melainkan untuk melayani oleh kasih (Gal. 5:13).

Persatuan dengan Kristus akan mentransformasi kehidupan orang percaya, bukan hanya sekedar mengalami pengampunan Allah bagi dosadosanya. Sincair F. Ferguson menyatakan,

Ketika kita dipersatukan dengan-Nya, juga ada pengertian bahwa hidup dan kuasa-Nya tersedia bagi kita untuk mentransformasi (mengubah) hidup kita. Kita bahkan dapat mengatakan bahwa ketika kita dipersatukan dengan Kristus, seluruh kehidupan masa lalu-Nya tersedia bagi kita, bukan hanya untuk menggantikan masa lalu kita (melalui pengampunan), tetapi juga secara aktual menguduskan hidup kita saat ini, sehingga masa lalu kita dapat dicegah untuk mendominasi hidup Kristen kita pada saat ini. Kita yang pada masa lalu telah merusak gambar Allah dengan dosa, dapat menatap wajah Kristus dan menemukan sumber kuasa dan kekudusan yang kita perlukan supaya kuasa dosa masa lalu kita tidak menghancurkan kita pada masa kini. $^{5}$

\footnotetext{
${ }^{3}$ George Eldon Ladd, Teologi Perjanjian Baru Jilid 2 (Bandung: Kalam Hidup, 1999), 297.

${ }^{4}$ Ibid., 297.

${ }^{5}$ Sinclair B. Ferguson, Kehidupan Kristen: Sebuah Pengantar Doktrinal (Surabaya: Momentum, 2007), 146.
} 
Persatuan dengan Kristus menghadirkan Kristus dalam diri orang percaya dan ini adalah landasan bagi kepemilikan semua harta rohani, pengharapan akan kemuliaan, dan vitalitas rohani bagi orang percaya. ${ }^{6}$

Pada kenyataannya selalu ada kemungkinan orang percaya meremehkan dosa dan terus berkompromi dengan dosa dalam kehidupan mereka. Mereka bertekun dalam dosa karena beranggapan kasih karunia Allah akan selalu melimpah untuk mengatasi dosa-dosa mereka dan itu berarti kemuliaan bagi Allah akan semakin besar. Pandangan ini tampak jelas dalam pernyataan Voltaire yang terkenal, "Allah akan mengampuni; itu adalah urusan-Nya." Demikian pula W. H. Auden mengemukakan pernyataan yang serupa, "Saya suka melakukan kejahatan. Allah suka mengampuninya. Sungguh dunia diatur dengan mengagumkan."

Sejarah membuktikan ada orang yang hidup dengan pandangan seperti itu. Gregory Rasputin seorang biarawan Rusia pernah mengajarkan dan memberikan contoh doktrin keselamatan melalui pengulangan berbuat dosa dan bertobat. Dia meyakini bahwa orang yang paling berdosa membutuhkan paling banyak pengampunan, jadi orang yang terus hidup bergelimangan dosa akan menikmati lebih banyak anugerah pengampunan Allah daripada pendosa biasa, setiap kali ia bertobat. $^{8}$

Masalah lain berhubungan dengan nas Roma 6:1-14 muncul ketika Paulus menyatakan bahwa jalan masuk ke dalam persatuan dengan Kristus adalah melalui baptisan (Rm. 6:3). Baptisan menyatukan seseorang dengan kematian, penguburan dan kebangkitan Kristus. Di sini Paulus menggunakan frasa "dibaptis ke dalam Kristus.” Penggunaan frasa ini menimbulkan masalah penafsiran, baptisan apakah yang dimaksudkan oleh Paulus?

Menurut van den End, baptisan yang dimaksudkan oleh Paulus adalah upacara atau sakramen baptisan air/baptisan Kristen. Baginya, dalam sakramen baptisan seseorang mengenal kesatuannya dengan Kristus maka bukan iman yang menjadi dasar atau titik tolak baptisan. Baptisan berdasarkan rahmat Allah dan dengan iman kita menerima anugerah itu, ${ }^{9}$ sehingga keselamatan seseorang yang terletak dalam persekutuannya dengan kematian dan kebangkitan Kristus, mendahului

\footnotetext{
${ }^{6}$ Millard J. Erickson, Teologi Kristen Volume 3 (Malang: Gandum Mas, 2004), 163.

7 Thomas L. Constable, "Notes on Romans," diakses 12 Maret 2014, http://soniclight.com/constable/notes/pdf/romans.pdf

${ }^{8}$ F. F. Bruce, The Letter of Paul to The Romans: An Introduction and Commentary (Leicester: Inter-Varsity Press, 1999), 127.

${ }^{9}$ Th. van den End, Tafsiran Alkitab Surat Roma (Jakarta: BPK Gunung Mulia, 2008), 320.
} 
imannya. ${ }^{10}$ Ini adalah pandangan kaum sakramentarian yang menjadikan anugerah Allah sebagai sesuatu yang substansial (inti) dan gereja sebagai depositnya dapat menyalurkannya melalui baptisan. II Sedangkan menurut Hagelberg yang Paulus maksudkan dengan frasa ini adalah baptisan Roh. Bagi dia, baptisan "dalam" atau "atas" nama Kristus dipakai pada waktu menceritakan upacara baptisan air, sedangkan baptisan "ke dalam Kristus" menceritakan baptisan Roh. ${ }^{12}$

\section{Analisis Struktur Nas Roma 6:1-14}

Paulus mengawali nas ini dengan sebuah pertanyaan (6:1) yang merupakan kesimpulan yang dapat muncul dari kebenaran yang dijelaskan di dalam Roma 5:12-21. Pertanyaan ini sekaligus menjadi peralihan untuk memasuki topik baru yang akan dijelaskan selanjutnya oleh Paulus. Ayat 2 merupakan jawaban atas pertanyaan tersebut, dan bertolak dari jawaban ini, Paulus mengungkapkan konsep tentang persatuan dengan kematian dan kebangkitan Kristus yang diuraikan dalam ayat 3-13. Kemudian Paulus memberikan suatu kesimpulan di dalam ayat 14 .

Berikut ini adalah struktur lengkap nas Roma 6:1-14:

A. Pertanyaan Tentang Bolehkah Bertekun Dalam Dosa (6:1).

B. Jawaban: Sekali-kali Tidak (6:2).

C. Persatuan dengan Kristus Sebagai Dasar Jawaban (6:3-13).

1. Baptisan Sebagai Jalan Masuk ke dalam Persatuan dengan Kristus $(6: 3-5)$

2. Hasil Persatuan dengan Kristus (6:6-11).

a. Kematian Manusia Lama (6:6-7).

b. Hidup dengan Kristus (6:8-9).

c. Hidup Bagi Allah (6:10-11).

3. Realisasi Hasil Persatuan dengan Kristus (12-13).

a. Menolak Dosa (6:12).

b. Tidak Menyerahkan Anggota Tubuh kepada Dosa (6:13a).

c. Menyerahkan Diri kepada Allah (6:13b).

d. Menyerahkan Anggota Tubuh kepada Allah (6:13c)

D. Kesimpulan (6:14).

\footnotetext{
${ }^{10}$ Ibid., 304.

${ }^{11}$ Louis Berkhof, Teologi Sistematika Volume 4: Doktrin Keselamatan (Surabaya: Momentum, 2010), 88.

${ }^{12}$ Dave Hagelberg, Tafsiran Roma dari Bahasa Yunani (Bandung: Kalam Hidup, 2013), 124.
} 


\section{Bolehkah Bertekun dalam Dosa?}

"Jika demikian, apakah yang hendak kita katakan? Bolehkah kita bertekun dalam dosa, supaya semakin bertambah kasih karunia itu? Sekali-kali tidak!" Pertanyaan yang ditulis Paulus dalam ayat ini merupakan pertanyaan yang dapat saja muncul sebagai akibat dari pengajaran yang disampaikan sebelumnya dan lebih khusus dari pernyataannya dalam Roma 5:20, "Tetapi hukum Taurat ditambahkan supaya pelanggaran menjadi semakin banyak; dan di mana dosa bertambah banyak, di sana kasih karunia menjadi berlimpah-limpah." Sebelumnya Paulus telah mengatakan bahwa seseorang dibenarkan bukan karena melakukan hukum Taurat (Rm. 3:20), melainkan hanya karena kasih karunia (Rm. 5:16). Akibatnya orang bisa saja menyimpulkan, "Marilah kita berbuat dosa sebanyak-banyaknya supaya kasih karunia menjadi berlimpah-limpah dan karena itu kita diselamatkan." Thomas Schreiner mengatakan apabila multifikasi dosa ditempatkan secara tajam pada kasih karunia Allah yang tak tertandingi, maka berbuat dosa akhirnya tampak bermanfaat. ${ }^{13}$ Namun, tidaklah demikian yang dimaksudkan Paulus dengan pernyataannya tersebut.

"Jika demikian, apa yang hendak kita katakan?" dalam teks Yunani, Ti oun eroumen merupakan rumusan khas Paulus dalam surat Roma ketika ia ingin menyimpulkan sesuatu atau untuk menandakan perpindahan tiba-tiba kepada suatu topik yang baru atau sebagai cara untuk menarik perhatian kepada beberapa pernyataan penting $(3: 5 ; 7: 7 ; 9: 14 ; 8: 31$; 9:30). ${ }^{14}$ Kata eroumen adalah kata kerja yang berarti "kita akan katakan." Ini menyatakan bahwa pertanyaan yang menyusulnya adalah sesuatu yang berpotensi untuk ditanyakan oleh orang-orang.

"Bolehkah kita bertekun dalam dosa, ...?" Kata epimenômen adalah kata kerja yang berasal dari kata epimenô yang berarti tinggal, tetap. ${ }^{15}$ Penggunaan kata sandang tê menandakan kata hamartia sebagai kata benda dalam kasus datif ${ }^{16}$ yang menunjukkan tujuan dari suatu pekerjaan. Sehingga kalimat epimenômen tê hamartia dapat juga diterjemahkan menjadi, "Bolehkah kita terus tinggal di dalam dosa?" atau "Apakah kita akan terus tinggal dalam dosa?" Dosa dalam konteks ini

${ }^{13}$ Thomas Schreiner, Romans (Grand Rapids: Baker, 1998), 298.

${ }^{14}$ Robert Jamieson, A. R. Fausset dan David Brown, A Commentary Critical, Experimental, and Practical Old and New Testaments (Grand Rapids, Michigan: William B. Eerdmans Publishing Company, 1990), 224.

${ }^{15}$ Hasan Sutanto, Perjanjian Baru Interlinear Yunani-Indonesia dan Konkordansi Perjanjian

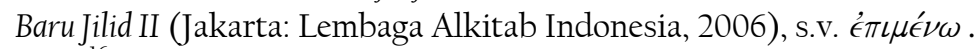

${ }^{16}$ Kasus datif dapat dipakai untuk menyatakan tempat (lokatif), yaitu keadaan sesuatu yang tidak bergerak. J. W. Wenham, Bahasa Yunani Koine (Malang: SAAT, 1987), 25. 
digambarkan sebagai penguasa sesuai dengan Roma 5:21, "supaya, sama seperti dosa berkuasa dalam alam maut,..." Sehingga "tinggal dalam dosa" berarti "tinggal dalam lingkungan kuasanya." Orang percaya yang terus tinggal di dalam dosa berarti ia tinggal di dalam lingkungan kuasa dosa dan tidak menyadari bahwa ia telah dipindahkan dari lingkungan itu dan masuk ke dalam lingkungan hidup yang baru.

"Bolehkah kita bertekun dalam dosa, supaya semakin bertambah kasih karunia itu?" Lewat pertanyaan ini jelaslah yang diserang adalah pengajaran Paulus tentang pembenaran sebagai kasih karunia atau anugerah Allah. Pengajaran bahwa kasih karunia Allah sanggup mengatasi dosa manusia, bahkan di mana dosa bertambah banyak di situlah kasih karunia semakin melimpah, dapat mendorong orang untuk terus hidup di dalam dosa. Akibatnya Paulus dipandang mengajarkan pembenaran yang tidak beralasan. ${ }^{17}$ Padahal Paulus mengajarkan bahwa banyaknya dosa manusia sebelum pertobatan mereka menunjukkan berlimpahnya anugerah Allah dalam pengampunan atas dosa-dosa itu, namun tidak demikian jika mereka berlimpah dalam dosa setelah mereka bertobat. Paulus merujuk pada masa lampau bukan pada masa yang akan datang. ${ }^{18}$

Paulus dengan tegas menjawab, "Sekali-kali tidak!" Kata ginomai dapat memiliki banyak arti dalam berbagai konteks, ${ }^{19}$ dan dalam konteks ini berarti "terjadi." Penggunaannya dalam modus optatif ${ }^{20}$ yang disertai dengan sanggahan mê membuatnya dapat diartikan "kiranya tidak terjadi!" atau lebih tegas "sekali-kali tidak!"

"Bukankah kita telah mati bagi dosa, bagaimanakah kita masih dapat hidup di dalamnya?" Paulus menggunakan kata otines (bukankah) yang mengajak pembaca untuk merenungkan apa artinya telah menjadi Kristen. ${ }^{21}$ Artinya orang Kristen itu sesungguhnya telah mati bagi dosa maka dia tidak hidup lagi dalam dosa.

\footnotetext{
${ }^{17}$ Robert Jamieson, A. R. Fausset dan David Brown, A Commentary Critical, Experimental, and Practical Old and New Testaments (Grand Rapids, Michigan: William B. Eerdmans Publishing Company, 1990), 224.

${ }^{18}$ Matthew Poole, A Commentary on The Holy Bible Volume III (Mclean, Virginia: Macdonald Publishing Company, n.d.), 496.

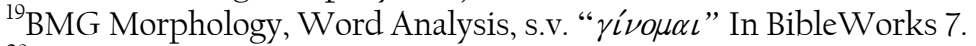

${ }^{20}$ Modus Optatif jarang dipakai dalam Perjanjian Baru. Modus ini menyatakan keadaan yang lebih "tak tentu" lagi. Dalam Perjanjian Baru hanya dua kata optatif yang

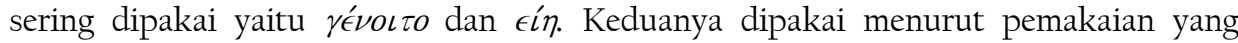
paling biasa, yaitu 1) untuk menyatakan suatu keinginan, permohonan dan 2) dalam pertanyaan yang tidak langsung. J. W. Wenham, Bahasa Yunani Koine, diterjemahkan dan disadur oleh Lynne Newell (Malang: SAAT, 1987), 151.

${ }^{21}$ Leon Morris, The Epistle to the Romans (Grand Rapids, Mich.: W.B. Eerdmans, 1988.), 245.
} 
Paulus menjelaskan dasar dari sanggahannya terhadap pertanyaan di atas. Secara logis pernyataan ini bertentangan, "Seseorang telah mati bagi dosa tetapi masih dapat hidup di dalamnya." Hal ini seharusnya tidak boleh terjadi. Kata apethanomen adalah kata kerja aorist indikatif aktif orang pertama jamak yang berasal dari kata apothneskô ${ }^{22}$ yang berarti "telah mati," jadi merujuk pada peristiwa yang sudah terjadi di masa lampau. Kata hamartia $a^{23}$ adalah kata benda datif ${ }^{24}$ tunggal yang berarti "dosa." Di sini dosa digambarkan sebagai penguasa, sehingga kalimat otines apethanomen te hamartia dengan tepat diterjemahkan "kita telah mati terhadap (bagi) dosa." Artinya, orang percaya telah mati terhadap dosa yang berperan sebagai penguasa. Tidak menyatakan bahwa ia telah mati terhadap perbuatan-perbuatan dosa atau ia tidak dapat lagi berbuat dosa. Menurut Newman dan Nida, karena kata mati di sini adalah kata kerja, maka mati bagi dosa berarti "berhenti berbuat dosa." ${ }^{25}$ Van den End menafsirkan "telah mati" di sini mengacu pada saat tertentu di masa lalu (aoristus), sedangkan "bagi dosa" merupakan terjemahan harfiah tei hamartiai, yang mengungkapkan hubungan (yang ditiadakan) antara pemilik dan miliknya. Sehingga "kita telah mati bagi dosa" berarti "kita bukan milik dosa lagi" ${ }^{26}$ Lebih lanjut Van den End menyatakan:

Kata-kata 'telah mati' mengacu pada peristiwa di masa lampau. Halnya di sini tidak mengenai perjuangan melawan dosa dalam kehidupan seharihari, yang menjadi panggilan orang Kristen. Peristiwa itu bersifat menentukan, sedemikian rupa hingga dibandingkan dengan kematian. Kata-kata 'telah mati' itu mengacu pada peristiwa yang kita alami lebih daripada perbuatan kita. Sebab 'mati' bukanlah sesuatu yang aktif kita lakukan, tetapi yang pasif kita alami. ${ }^{27}$

Pandangan ini didukung oleh Ridderbos yang menyatakan, "Kalimat kita telah mati bagi dosa tidak menunjuk kepada realitas etis atau mistis, melainkan keberbagian jemaat dalam kematian dan penguburan Kristus

${ }^{22} \alpha \dot{\alpha} \pi \epsilon \theta \dot{\alpha} \nu o \mu \epsilon \nu$ verb indicative aorist active lst person plural from avpoqnh,|skw

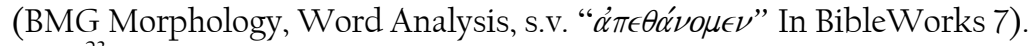

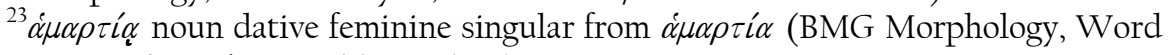

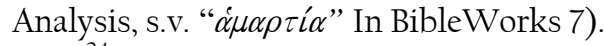

${ }^{24}$ Ini adalah datif kerugian (incommodi) atas pertanyaan "merugikan siapa?" B. F. Drewes, Wilfrid Haubeck dan Heinrich von Siebenthal, Kunci Bahasa Yunani Perjanjian Baru: Surat Roma hingga Kitab Wahyu (Jakarta: BPK Gunung Mulia, 2006), 458.

${ }^{25}$ Barclay M. Newman dan Eugene A. Nida, Pedoman Penafsiran Alkitab Surat Paulus kepada Jemaat di Roma, diadaptasi oleh M. K. sembiring dan P. G. Katoppo dari A Handbook on Paul's Letter to the Romans (Jakarta: LAI, 2012), 124.

${ }^{26}$ Th. van den End, Tafsiran Alkitab: Surat Roma (Jakarta: BPK Gunung Mulia, 2008), 300.

${ }^{27}$ Ibid., 301. 
dalam pengertian satu waktu, sejarah-penebusan." ${ }^{28}$ Bagi Ridderbos, pengertian "kita telah mati bagi dosa" bukan merujuk pada perilaku seseorang yang tidak berbuat dosa lagi atau menolak dosa (etis), juga bukan sesuatu yang secara otomatis membuat seseorang tidak dapat berbuat dosa lagi (mistis). Tetapi dalam konteks ini merujuk pada keikutsertaan seseorang dengan kematian Kristus dalam sejarah yang terjadi ketika ia menerima Kristus sebagai Juruselamatnya.

Fakta bahwa orang percaya telah mati terhadap dosa adalah dasar pikiran Paulus yang utama. Ini adalah identitas orang percaya, dia telah mati terhadap dosa. Dalam pandangan Paulus ini adalah pemutusan hubungan yang pasti dengan dosa satu kali untuk selamanya. Oleh karena itu, orang percaya tidak boleh hidup dalam dosa. Jika ia hidup dalam dosa itu berarti ia bukan orang percaya. Jika dosa dipandang sebagai suatu dunia atau lingkungan, maka orang percaya tidak akan terus hidup di dalam dunia atau lingkungan itu, karena ia telah mati terhadap dunia itu dan telah dipindahkan ke dunia yang lain. ${ }^{29}$

\section{Persatuan dengan Kristus Sebagai Dasar Jawaban}

\section{Baptisan Sebagai Jalan Masuk (6:3-5)}

Rumusan "tidak tahukah kamu" adalah salah satu karakteristik dari tulisan-tulisan Paulus. Di sini ia menggunakan e agnoeite dan pada bagian lain ia menggunakan ouk hoidate, seperti dalam 6:16. Rumusan ini ia gunakan untuk menyatakan suatu kebenaran umum yang ia yakini sudah diketahui oleh pembaca suratnya. Dalam konteks ini, Paulus yakin jemaat Roma telah mengetahui makna dari baptisan bahwa semua orang yang telah dibaptis dalam Kristus berarti telah dibaptis dalam kematianNya.

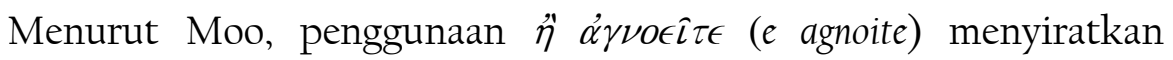
bahwa jemaat Kristen di Roma telah mengetahui beberapa hal yang akan disampaikan oleh Paulus. Barangkali mereka telah mengetahui makna dari baptisan tetapi belum memahami beberapa implikasinya. Salah satu implikasi yang Paulus tegaskan adalah baptisan ke dalam Kristus melibatkan baptisan ke dalam kematian-Nya. ${ }^{30}$ Menurut Cranfield, "dibaptis ke dalam Kristus" secara sederhana merupakan bentuk yang

${ }^{28}$ Herman Ridderbos, Paulus: Pemikiran Utama Theologinya (Surabaya: Momentum, 2010), 214.

${ }^{29}$ John Murray, The Epistle to The Romans Volume I (Grand Rapids, Michigan: Wm. B. Eerdmans Publishing Co., 1964), 213.

${ }^{30}$ Douglas J. Moo, "Exegetical Notes Romans 6:1-14," diakses 12 Maret 2014, http://www.djmoo.com/articles/romans6.pdf 
lebih pendek dari "dibaptis di dalam nama Kristus." ${ }^{31}$ Bagi dia, ayat ini hanya menceritakan "baptisan Kristen" (rupanya dengan baptisan air). ${ }^{32}$ Berdasarkan pengamatannya, Hagelberg menyimpulkan bahwa Paulus di sini sedang merujuk kepada baptisan Roh. Baptisan "dalam" atau "atas" nama Kristus (Mat. 28:19, Kis. 2:38; 8:16) dipakai pada waktu upacara baptisan air diceritakan, sedangkan baptisan "ke dalam Kristus" (Rm. 6:3 dan Gal. 3:27) menceritakan baptisan Roh. ${ }^{33}$ Kesimpulan ini mendapat sanggahan dari Carson. Menurutnya, lebih baik dipahami bahwa Paulus menggunakan baptisan air sebagai "peringkas" (shorthand) untuk pengalaman pertobatan awal orang Kristen. Sebagaimana Perjanjian Baru secara konsisten menggambarkan baptisan air sebagai komponen pokok dari pertobatan (Kis. 2:38, 1 Ptr. 3:21). ${ }^{34}$

Pandangan Wiersbe sejalan dengan itu bahwa dari paragraf ini (ayat 3-4) tampak dalam pikiran Paulus terdapat dua unsur, harfiah dan kiasan. Paulus menggunakan pengalaman baptisan air pembacanya untuk mengingatkan mereka kepada pengidentifikasian diri mereka dengan Kristus melalui baptisan Roh Kudus. ${ }^{35}$ Moo memiliki pendapat yang sama. Baginya, kata benda baptisma yang dipakai dalam ayat 4 adalah kata yang umum digunakan Paulus untuk menunjuk baptisan air. Tetapi ini tidak meniadakan referensi tentang baptisan Roh Kudus dan keterlibatan iman dalam respons terhadap Kristus. Iman sebagai pemberian Roh Kudus dan baptisan air adalah dua bagian yang melekat dari pengalaman tunggal "permulaan-pertobatan" orang percaya. ${ }^{36}$

Carson dalam pandangannya tidak menyatakan bahwa baptisan menyelamatkan atau melalui baptisan seseorang mengalami kelahiran kembali. Ia dengan tegas menyatakan bahwa baptisan di dalam dan dari dirinya sendiri tidak memiliki kuasa untuk mengubahkan atau membawa seseorang masuk ke dalam hubungan dengan Kristus. Itu hanya terjadi jika baptisan terhubung dengan iman yang sejati. Dari

${ }^{31}$ C. E. B. Cranfield, A Critical and Exegetical Commentary on the Epistle to the Romans (Edinburgh: T\&T Clark, 2000), 301. Dikutip oleh Ryan Collman, Exegesis of Romans 6:1-

14: Dead to Sin and Alive in Christ; diakses 12 Maret 2014, www.academia.edu/5682071/Romans_6_1-14_Dead_to_sin_and_Alive_in_Christ

${ }^{32}$ Dave Hagelberg, Tafsiran Roma dari Bahasa Yunani (Bandung: Kalam Hidup, 2013), 124.

${ }^{33}$ Hegelberg, 124.

${ }^{34}$ D. A. Carson et al., New Bible Commentary: 21st Century Edition (Leicester: InterVarsity Press, 1995), 1135-1136.

${ }^{35}$ Warren W. Wiersbe, The Bible Exposition Commentary. 2 vols. (Wheaton, Ill.: Victor Books, Scripture Press, 1989), I:531. Dikutip oleh Thomas L. Constable, "Notes on Romans," diakses 12 Maret 2014, http://soniclight.com/constable/notes/pdf/romans.pdf

${ }^{36}$ Douglas J. Moo, "Exegetical Notes Romans 6:1-14," diakses 12 Maret 2014, http://www.djmoo.com/articles/romans6.pdf 
Roma 1-5 jelas bahwa pada akhirnya, imanlah yang menjadi elemen terpenting dalam proses ini. ${ }^{37}$

Bruce juga meyakini maksud Paulus tentang baptisan di sini adalah baptisan Kristen/air. Bertolak dari ayat 3, ia menyatakan bahwa dalam tulisan-tulisan Paulus, baptisan tidak dipandang sebagai suatu "pilihan tambahan" (bisa dilakukan atau tidak) dalam kehidupan Kristen. Dalam masa para rasul, baptisan segera terjadi secara langsung menyusul pengakuan iman dalam Kristus. Kisah Para Rasul memberikan bukti yang luas tentang hal ini. Perkataan Paulus, "kita semua yang telah dibaptis..." menunjukkan bahwa ia menganggap semua jemaat Roma telah dibaptis dan tentunya itu terjadi sesuai dengan pengakuan iman mereka kepada Kristus. Iman dalam Kristus dan baptisan bukanlah dua pengalaman yang jauh berbeda sebagai bagian dari satu keseluruhan. Iman dalam Kristus adalah elemen pokok dalam baptisan, karena tanpa itu baptisan air sekalipun diikuti dengan kata-kata yang tepat, bukanlah baptisan Kristen. ${ }^{38}$ Tidak demikian halnya dengan van den End. Ia setuju bahwa yang Paulus maksudkan di sini adalah baptisan Kristen, tetapi ia memandang sakramen baptisanlah yang mempersatukan seseorang dengan Kristus, sehingga bukan iman yang menjadi dasar atau titik tolak baptisan, melainkan rahmat Allah dan anugerah itu diterima dengan iman. 39

Berdasarkan teks dalam ayat 4 yang menggunakan kata baptisma, dan juga konteksnya di mana Paulus ingin membangun kesadaran dalam diri jemaat tentang hubungan mereka dengan Kristus. Penulis menarik kesimpulan bahwa di sini Paulus menggunakan baptisan yang merupakan pengalaman nyata yang telah dialami di luar diri jemaat untuk menyadarkan mereka tentang apa yang sesungguhnya telah terjadi di dalam diri mereka lewat pekerjaan Roh Kudus. Kesimpulan ini juga berada dalam konteks bahwa Paulus menggunakan baptisan Kristen tidak pernah terlepas dari iman yang sejati kepada Kristus. Dalam kehidupan gereja mula-mula, iman yang menyelamatkan dan baptisan secara praktisnya adalah sinonim. ${ }^{40}$ Ketika Paulus menggunakan baptisan, itu harus dipahami mewakili keseluruhan pengalaman awal mula pertobatan seseorang menjadi orang percaya. Kesimpulan ini berbeda dengan pandangan van den End di atas dan pernyataannya pada

\footnotetext{
${ }^{37}$ D. A. Carson et al., New Bible Commentary: 21st Century Edition (Leicester: InterVarsity Press, 1995), 1136.

${ }^{38}$ F. F. Bruce, The Letter of Paul to The Romans: An Introduction and Commentary (Leicester: Inter-Varsity Press, 1999), 128-129.

${ }^{39}$ Th. van den End, Tafsiran Alkitab: Surat Roma (Jakarta: BPK Gunung Mulia, 2008), 320.

${ }^{40}$ George Eldon Ladd, Teologi Perjanjian Baru Jilid 2 (Bandung: Kalam Hidup, 1999), 342.
} 
bagian lain bahwa keselamatan kita, yang terletak dalam persekutuan kita dengan kematian dan kebangkitan Kristus (melalui baptisan), mendahului iman kita. ${ }^{41}$ Berbeda juga dengan penafsiran yang menekankan kehadiran kematian dan kebangkitan Kristus melalui sakramen baptisan. ${ }^{42}$

Pertanyaan berikut yang muncul adalah apa makna dibaptis ke dalam Kristus Yesus? Bagi Moo, sekalipun ia mengakui bahwa baptisan ke dalam Kristus Yesus mungkin merupakan bentuk yang lebih ringkas/pendek dari baptisan ke dalam nama Kristus Yesus, namun dalam konteks ini ia lebih menekankan maknanya pada persatuan orang percaya dengan Kristus Yesus. ${ }^{43}$ Pandangan Moo yang berfokus pada persatuan dengan Kristus ini lebih popular. Teks yang paling dekat dengan formula ini dapat ditemukan di dalam Galatia 3:27-28. Di sana Paulus juga menggunakan bentuk eis Christon untuk menjelaskan tentang ke dalam siapa kita dibaptis dan bahwa semua orang yang telah dibaptis ke dalam Kristus adalah satu di dalam Dia. ${ }^{44}$ Newman dan Nida juga mengakui bahwa pada umumnya disepakati, "ke dalam Kristus Yesus" menunjuk pada makna "ke dalam persekutuan dengan Kristus Yesus", atau "dipersatukan dengan Kristus Yesus." 45

Ketika seseorang dipersatukan dengan Kristus maka ia akan ikut serta dengan semua yang terjadi pada diri Kristus. Ia ikut serta dalam kematian, penguburan dan kebangkitan Kristus yang terjadi dalam sejarah. Penggunaan dalam bentuk aorist dari kata-kata "dibaptis"

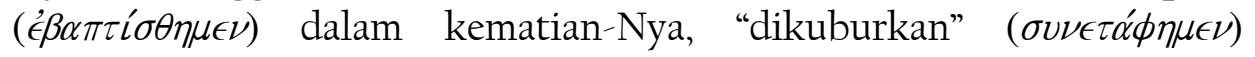

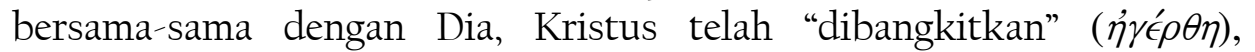
menyatakan bahwa semuanya merujuk kepada peristiwa yang telah dialami oleh Kristus dalam sejarah. Bagaimana seseorang bisa ikut serta dalam semua peristiwa ini? Petunjuknya terdapat dalam kalimat, "oleh baptisan dalam kematian," yang diterjemahkan dari dia tou baptismatos eis ton thanaton. ${ }^{46}$ Melalui penggunaan kata $\delta\left\llcorner\dot{\alpha}^{47}\right.$ dan baptismatos dalam

\footnotetext{
${ }^{41}$ Th. van den End, Tafsiran Alkitab: Surat Roma (Jakarta: BPK Gunung Mulia, 2008), 304.

${ }^{42}$ Douglas J. Moo, “Exegetical Notes Romans 6:1-14," diakses 12 Maret 2014 , http://www.djmoo.com/articles/romans6.pdf

${ }^{43}$ Ibid.

${ }^{44}$ Ryan Collman, Exegesis of Romans 6:1-14: Dead to Sin and Alive in Christ, diakses 12 Maret 2014, www.academia.edu/5682071/Romans_6_1-

14_Dead_to_sin_and_Alive_in_Christ

${ }^{45}$ Barclay M. Newman dan Eugene A. Nida, Pedoman Penafsiran Alkitab Surat Paulus kepada Jemaat di Roma, diadaptasi oleh M. K. sembiring dan P. G. Katoppo dari A Handbook on Paul's Letter to the Romans (Jakarta: LAI, 2012), 125.

${ }^{46}$ BGT Version, BibleWorks Greek LXX/BNT In BibleWorks 7.

${ }^{47} \delta \iota \dot{\alpha}$ preposition genitive from dia, (BMG Morphology, Word Analysis, s.v. $\delta \iota \dot{\alpha}$ In BibleWorks 7).
} 
kasus genitif menjelaskan baptisan sebagai cara yang melaluinya seseorang dihubungkan dengan peristiwa-peristiwa itu. Ridderbos menyatakan:

Saat kita dibaptis masuk ke dalam Kristus dan menjadi milik-Nya, maka apa yang pertama-tama terjadi di dalam Dia juga sah bagi kita. Kita bahkan bisa disebut telah dikubur bersama-sama Kristus dan mati bagi dosa. Ini bukan hanya suatu peristiwa sakramental, tetapi menunjukkan keberbagian orang percaya (melalui sakramen baptisan) dalam peristiwa penebusan di Golgota dan di taman kebangkitan. ${ }^{48}$

Jadi melalui baptisan orang percaya turut mengalami apa yang dialami oleh Kristus. Ini bukan sekedar simbolis, kita dikuburkan sama seperti Kristus dikuburkan, tetapi dengan jelas dikatakan, kita dikuburkan bersama-sama dengan Dia. Sebagaimana penguburan Kristus menegaskan kematian-Nya sungguh-sungguh terjadi, maka penguburan orang percaya juga menegaskan bahwa ia sungguh-sungguh telah mati bersama Kristus. Setelah sungguh-sungguh mati dan dikuburkan bersama-sama dengan Kristus, ia juga bisa berbagian dengan kebangkitan-Nya.

Dalam konteks Roma 6:1-4, Hendrikus Boers berpendapat bahwa Paulus memberikan pemahaman yang spesifik tentang baptisan, namun hal itu tidak menjadi fokus Paulus untuk didiskusikan tetapi memakai istilah baptisan untuk mendukung maksud pertanyaan retoris Not at all! We who died to the missing-of-the-mark, how will we still live in it? (ayat 2). ${ }^{49}$ Pendapat yang sama dinyatakan Moo bahwa pernyataan Paulus tentang baptisan bukan pusat pengajarannya tetapi penggunaan klausa tujuan yang mengikuti (ina artinya supaya) berisi suatu perbandingan antara (ôsper) kebangkitannya Kristus dan kehidupan orang percaya dalam suatu "hidup baru" (kainotêti zôês). ${ }^{50}$

Apakah tujuannya orang percaya ikut serta dengan peristiwa yang dialami oleh Kristus? "Supaya, sama seperti Kristus telah dibangkitkan dari antara orang mati oleh kemuliaan Bapa, demikian juga kita akan hidup dalam hidup yang baru." ${ }^{5 l}$ Penggunaan kata sambung hina yang disertai kata kerja aorist subjunktif peripatesômen ${ }^{52}$ menyatakan petunjuk

\footnotetext{
${ }^{48}$ Herman Ridderbos, Paulus: Pemikiran Utama Theologinya (Surabaya: Momentum, 2010), 215.

${ }^{49}$ Hendrikus Boers, "The structure and meaning of Romans 6:1-14." Catholic Biblical Quarterly 63 (2001): 665.

${ }^{50}$ Douglas Moo, "Romans 6:1-14." Trinity Journal 3 (September 1, 1982):216.

${ }^{51}$ BGT Version, BibleWorks Greek LXX/BNT In BibleWorks 7.

${ }^{52} \pi \epsilon \rho \iota \pi \alpha \tau \eta \dot{ } \sigma \omega \mu \epsilon \nu$ verb subjunctive aorist active lst person plural from peripate, $w$

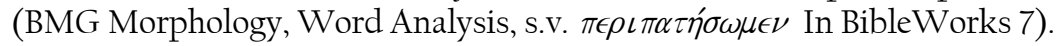


maksud, inilah tujuannya. Kata peripatesômen secara harfiah berarti "berjalan keliling" ${ }^{3}$ dan karena menggunakan bentuk aorist, maka sebaiknya diterjemahkan "menjalani" atau "menempuh". Sedangkan kata "baru" diterjemahkan dari kata kainoteti ${ }^{54}$ yang merupakan kata benda datif tunggal berasal dari kata kainotes yang berarti kebaruan. Kata "baru" di sini adalah lawan dari kata "lama", bermakna "berbeda dengan apa yang sudah ada; sama sekali lain dari yang sudah-sudah." ${ }^{55}$ Jadi tujuan dari keikutsertaan orang percaya dengan peristiwa yang dialami oleh Kristus dalam sejarah melalui persatuannya dengan Kristus adalah ia mati bagi dosa dan hidup untuk menjalani hidup yang baru.

Pemikiran tentang keikutsertaan orang percaya dengan Kristus dalam persatuan dengan-Nya merupakan pengembangan dari pokok bahasan sebelumnya dalam Roma 5:12-21 tentang perbandingan antara Adam dan Kristus. Adam adalah pemimpin manusia dalam dosa dan maut, sedangkan Kristus adalah pemimpin manusia dalam kebenaran dan hidup.

Ayat 5, "Sebab jika kita telah menjadi satu dengan apa yang sama dengan kematian-Nya, kita juga akan menjadi satu dengan apa yang sama dengan kebangkitan-Nya." Dalam bahasa Yunani, ei gar sumphutoi gegonamen tô homoiômati tou thanatou autou, alla kai tês anastaseôs esometha. ${ }^{56}$ Dalam bahasa asli memang tidak ada kalimat "menjadi satu dengan apa yang sama dengan" kebangkitan-Nya, tetapi perlu ditambahkan sesuai dengan konteks kalimat. Kata alla yang menyusul anak kalimat yang diawali dengan kata $\epsilon \dot{\iota}$ (jika), mengandung pengertian "maka pasti." Kemudian disusul dengan kata $\kappa \alpha i$ (juga) dan esometha ${ }^{58}$ yang merupakan kata kerja future indikatif middle orang pertama jamak, membuatnya mengandung pengertian bahwa apa yang terjadi pada kalimat pertama juga akan terjadi pada kalimat kedua. Karena itulah pada kalimat kedua perlu ditambahkan "menjadi satu dengan apa yang sama dengan."

Frasa "kita telah menjadi satu" adalah terjemahan dari sumphutoi gegonamen. Bentuk perfek dari kata gegonamen ${ }^{59}$ menunjukkan bahwa

\footnotetext{
${ }^{53}$ BMG Morphology, Word Analysis, s.v. $\pi \epsilon \rho \iota \pi \alpha \tau \epsilon ́ \omega$ In BibleWorks 7.

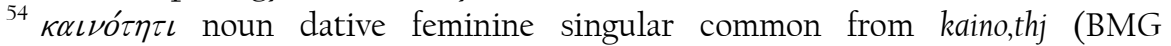

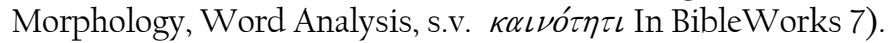

${ }^{55}$ Th. van den End, Tafsiran Alkitab: Surat Roma (Jakarta: BPK Gunung Mulia, 2008), 306.

${ }^{56}$ BGT Version, BibleWorks Greek LXX/BNT In BibleWorks 7.

${ }^{57}$ B. F. Drewes, Wilfrid Haubeck dan Heinrich von Siebenthal, Kunci Bahasa Yunani Perjanjian Baru: Surat Roma hingga Kitab Wahyu (Jakarta: BPK Gunung Mulia, 2006), 17.

${ }^{58} \epsilon \sigma o ́ \mu \epsilon \theta \alpha$ verb indicative future middle deponent lst person plural from eivmi,

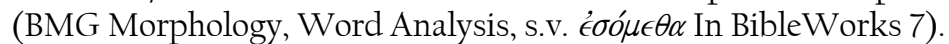

${ }^{59} \gamma \epsilon \gamma o ́ \nu \alpha \mu \epsilon \nu$ verb indicative perfect active lst person plural from gi,nomai (BMG

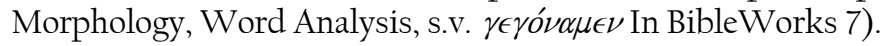


peristiwa orang percaya menjadi satu adalah peristiwa yang telah terjadi namun pengaruhnya masih tetap dirasakan. Kata sumphutoi yang berasal dari kata sumphutos dan diterjemahkan "menjadi satu" sebenarnya secara harfiah berarti "bertumbuh bersama" Jadi persatuan orang percaya dengan apa yang sama dengan kematianNya, di satu sisi mengandung pengertian peristiwa yang telah terjadi namun di sisi lain masih dalam proses. Melalui baptisan orang percaya telah bersatu dengan kematian Kristus yang adalah kematian terhadap dosa (Rm. 6:10), tetapi dalam kenyataan hidup ia terus menjalani proses untuk sungguh-sungguh mati terhadap dosa. Secara status orang percaya telah mati terhadap dosa, namun status ini harus terus ia realisasikan dalam kehidupan ini.

Apa yang telah terjadi dengan kematian orang percaya, itu juga akan terjadi dengan kebangkitannya. "Kita juga akan menjadi satu dengan apa yang sama dengan kebangkitan-Nya." Di sini terlihat perbedaan, kalimat pertama yang berhubungan dengan kematian menggunakan bentuk waktu perfek yang merujuk peristiwa masa lalu sedangkan kalimat kedua yang berhubungan dengan kebangkitan menggunakan bentuk waktu

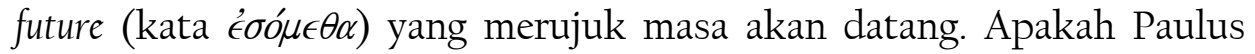
merujuk pada kebangkitan tubuh orang percaya yang akan terjadi pada masa depan? ${ }^{62}$ Ataukah kebangkitan secara rohani? $?^{63}$

Berdasarkan konteks Roma 6 dan juga konteks dari ayat 5 sendiri, bahwa yang Paulus maksudkan tentang persatuan orang percaya dengan apa yang sama dengan kematian Kristus bukanlah merujuk kepada kematian tubuhnya secara aktual, sekalipun kematian Kristus di sini merujuk pada kematian-Nya secara tubuh. Paulus merujuk pada kematian orang percaya secara rohani terhadap dosa sama dengan kematian Kristus yang adalah kematian terhadap dosa. Secara demikian juga seharusnya dipandang tentang persatuan orang percaya dengan kebangkitan Kristus. Paulus merujuk pada kebangkitan orang percaya secara rohani sebagai suatu hal yang secara logis harus terjadi menyusul kematiannya secara rohani. Pemakaian bentuk future di sini hanya untuk

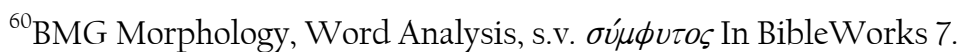

${ }^{61}$ B. F. Drewes, Wilfrid Haubeck dan Heinrich von Siebenthal, Kunci Bahasa Yunani Perjanjian Baru: Surat Roma hingga Kitab Wahyu (Jakarta: BPK Gunung Mulia, 2006), 17.

${ }^{62}$ Demikian penafsiran Carson, pertimbangannya adalah pemakaian bentuk waktu future dalam ayat 5 dan 8, tetapi dia tetap mengakui adanya kehadiran kuasa kebangkitan Kristus yang bekerja di dalam kita. D. A. Carson et al., New Bible Commentary: 21st Century Edition (Leicester: Inter-Varsity Press, 1995), 1136.

${ }^{63}$ Diakui bahwa bentuk future secara umum berhubungan dengan sesuatu yang akan terjadi, namun kadang-kadang bisa juga menunjuk pada sesuatu yang secara logika harus terjadi (contohnya: Gal. 6:5). Frank E. Gaebelein, The Expositors Bible Commentary Volume 10 (Grand Rapids, Michigan: Zondervan Publishing House, 1976), 69.
} 
menjelaskan apa yang akan terjadi menyusul kematian orang percaya terhadap dosa, yaitu kebangkitannya bagi hidup yang baru (Rm. 6:4b). Murray mengemukakan bahwa Paulus di sini tidak berurusan dengan kematian dan kebangkitan orang percaya secara fisik, melainkan kematiannya terhadap dosa dan kebangkitannya bagi kehidupan dalam Roh. $^{64}$

\section{Hasil Persatuan dengan Kristus}

\section{Kematian Manusia Lama (6:6-7)}

Ayat 6, "Karena kita tahu, bahwa manusia lama kita telah turut disalibkan, supaya tubuh dosa kita hilang kuasanya, agar jangan kita menghambakan diri lagi kepada dosa."

Paulus masih merujuk pada persatuan orang percaya dengan kematian Kristus, namun di sini dijelaskan lebih detail. Kematian Kristus adalah kematian melalui penyaliban, karena itu Paulus menegaskan bahwa manusia lama orang percaya telah turut disalibkan. Kata disalibkan, sunestaurothe ${ }^{65}$ adalah kata kerja aorist indikatif pasif yang menyatakan penyalibannya telah terjadi pada saat Kristus disalibkan. Frasa "Karena kita tahu," terjemahan dari ginoskontes dalam konteks ini bukanlah pengetahuan akal ataupun pengalaman batin semata, tetapi lebih merupakan kesadaran iman. ${ }^{66}$ Melalui iman orang percaya menerima penyaliban dan kematian manusia lamanya.

"Manusia lama" adalah terjemahan dari palaios anthropos. Kata

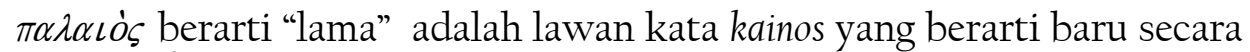
kualitas. ${ }^{67}$ Manusia lama di sini adalah keberadaan atau eksistensi manusia secara utuh yang berada dalam persekutuan dengan Adam. Kembali kepada konteks Roma 5:12-21 dan 1 Korintus 15, tentang perbandingan antara Adam dan Kristus. Dalam persekutuan dengan Adam sebagai manusia pertama, seluruh manusia adalah manusia lama, sedangkan dalam persekutuan dengan Kristus sebagai Adam terakhir seluruh manusia menjadi manusia baru. Manusia lama telah turut disalibkan berbicara tentang status atau posisi seseorang di dalam Adam yang telah mati atau diputuskan. Karena manusia pernah bersekutu dengan Adam, maka yang disalibkan dengan Kristus adalah tempatnya

\footnotetext{
${ }^{64}$ John Murray, The Epistle to The Romans Volume I (Grand Rapids, Michigan: Wm. B. Eerdmans Publishing Co., 1964), 218.

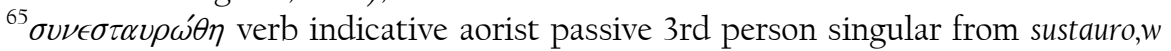

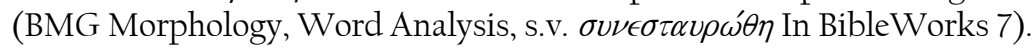

${ }^{66}$ Th. van den End, Tafsiran Alkitab: Surat Roma (Jakarta: BPK Gunung Mulia, 2008), 311.

${ }^{67}$ The Complete Word Study Dictionary (AMG International, Inc. in e-Sword - the

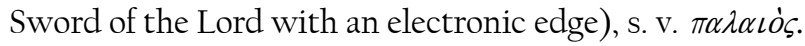


di dalam Adam, posisinya di dalam ciptaan yang lama, yang berada di bawah kuasa dosa dan maut. Di dalam Kristus, kita menjadi ciptaan yang baru, yang lama sudah berlalu, sesungguhnya yang baru sudah datang (2 Kor. 5:17). ${ }^{68}$

Status orang percaya sebagai manusia lama telah disalibkan atau telah mati, supaya tubuh dosanya hilang kuasanya. "Tubuh dosa" adalah terjemahan dari soma hamartias. Sekalipun dipakai kata tubuh, tidak berarti hanyalah bagian jasmani (daging) manusia. Paulus tidak pernah menggunakan konsep pembagian bahwa bagian yang jasmani (tubuh) yang berdosa sedangkan yang rohani (jiwa atau roh) tidak berdosa. Tubuh dosa berarti seluruh keberadaan diri manusia yang berdosa. Ridderbos menyatakannya sebagai modus eksistensi manusia hari ini yang dikuasai oleh dosa. ${ }^{69}$ Jadi dalam hal status sebagai manusia lama, orang percaya telah mati, tetapi ia masih hidup dalam tubuh yang masih dapat dipakai oleh dosa sebagai alat untuk memanifestasikan dirinya (dosa).

"Hilang kuasanya" adalah terjemahan dari kata katargethe ${ }^{70}$ yang merupakan bentuk aorist yang secara harfiah berarti membuat menganggur, tidak bekerja atau tidak aktif. ${ }^{71}$ Kata ini menggunakan bentuk aorist, maka "tubuh dosa kita hilang kuasanya" tetap merujuk kepada peristiwa kematian Kristus. Kematian Kristus disalib menjadi titik batas di mana dosa yang berkuasa atas manusia dalam persekutuannya dengan Adam telah berakhir. Dengan demikian konsekuensinya adalah dosa hilang kuasanya atas manusia dalam persekutuannya dengan Kristus. Dosa tidak lagi mempunyai kuasa mutlak yang mendominasi tubuh atau dengan kata lain tubuh bukan lagi budak dosa yang harus takluk pada keinginannya.

Tujuan akhir dari penyaliban manusia lama adalah "agar jangan kita menghambakan diri lagi kepada dosa." Penggunaan waktu sekarang dari kata menghambakan douleuein ${ }^{72}$ menunjukkan bahwa peristiwa penyaliban manusia lama yang dikenakan pada peristiwa kematian Kristus bertujuan untuk memberikan dorongan kepada orang percaya untuk menghidupi dalam kehidupan ini secara terus menerus apa yang

\footnotetext{
${ }^{68}$ Frank E. Gaebelein, The Expositors Bible Commentary Volume 10 (Grand Rapids, Michigan: Zondervan Publishing House, 1976), 70.

${ }^{69}$ Herman Ridderbos, Paulus: Pemikiran Utama Theologinya (Surabaya: Momentum, 2010), 216.

${ }^{70} \kappa \alpha \tau \alpha \rho \gamma \eta \theta \hat{\eta}$ verb subjunctive aorist passive 3rd person singular from katarge,w

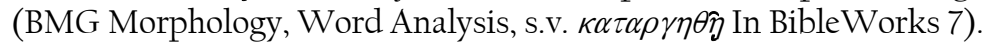

${ }^{71}$ The Complete Word Study Dictionary (AMG International, Inc. in e-Sword - the Sword of the Lord with an electronic edge), s. v. $\kappa \alpha \tau \alpha \rho \gamma^{\prime} \omega$.

${ }^{72} \delta o v \lambda \epsilon \cup \in \epsilon \iota \nu$ verb infinitive present active from douleuô (BMG Morphology, Word

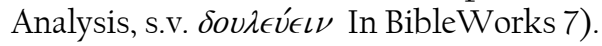


telah menjadi kesadaran imannya. Perbudakan dosa atas tubuh telah berakhir, karena itu jangan lagi ia menghambakan diri pada dosa.

Ayat 7, "Sebab siapa yang telah mati, ia telah bebas dari dosa." Dalam bahasa Yunani ho gar apothanôn dedikaiôtai apo tês hamartias. ${ }^{73}$ Ini adalah kutipan dari pepatah kaum rabi yang sangat populer, artinya kematian yang dialami oleh seseorang mengakibatkan hancurnya genggaman dosa pada orang itu. ${ }^{74}$ Kata dedikaiôtai yang merupakan kata kerja perfek indikatif pasif orang ketiga tunggal ${ }^{75}$ dan diterjemahkan "bebas" secara harfiah sebenarnya berarti "dibenarkan." ${ }^{76}$ Paulus tidak pernah berkata bahwa kematian seseorang secara fisik dapat membenarkan atau membebaskan dia dari dosanya. Jika demikian, ia tidak akan lagi mengalami penghakiman dan penghukuman akhir atas dosanya. Pastilah Paulus telah mengenakan makna baru pada pepatah itu yang sesuai dengan uraiannya pada ayat-ayat sebelumnya. Kematian yang dimaksudkan oleh Paulus di sini tentunya merujuk kepada kematian orang percaya bersama dengan Kristus melalui baptisan ke dalam kematian-Nya. Dengan demikian, "bebas dari dosa" berarti berakhirnya hubungan dengan dosa. Ayat ini hanyalah suatu pernyataan singkat untuk memperkuat kebenaran yang dinyatakan di dalam ayat $6 .{ }^{77}$

Seseorang yang telah bersatu dengan apa yang sama dengan kematian Kristus berarti ia tidak lagi berada di bawah kuasa dosa, karena kematiannya adalah kematian bagi dosa. Di sini dosa tetap dipandang sebagai penguasa yang dapat membelenggu atau memperbudak seseorang. Dosa tidak lagi berkuasa atas orang yang telah mati bersama dengan Kristus, karena ia tidak lagi berada di dalam ai $\omega \nu / a i o n$ lama di mana dosa memerintah. Jadi bebas dari dosa berarti bebas dari kuasa dosa. Ini tidak berarti orang percaya tidak dapat lagi berbuat dosa; ia masih dapat menghambakan diri kepada dosa, tetapi ia tidak harus melakukannya atau ia mempunyai kuasa untuk menolaknya. ${ }^{78}$

Bentuk perfek dari kata $\delta \epsilon \delta \iota \kappa \alpha i ́ \omega \tau \alpha \iota$ menjelaskan bahwa sejak seseorang bersatu dengan kematian Kristus, ia bebas dari dosa dan akan terus menikmati kebebasan itu. Ini juga merupakan kesadaran iman yang

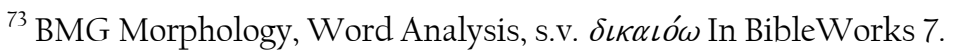

${ }^{74}$ D. A. Carson et al., New Bible Commentary: 21st Century Edition (Leicester: InterVarsity Press, 1995), 1136.

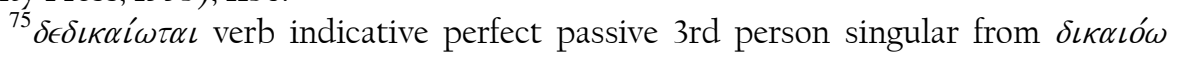
(BMG Morphology, Word Analysis, s.v. $\delta \epsilon \delta \iota \kappa \alpha i \omega \tau \alpha \iota$ In BibleWorks 7).

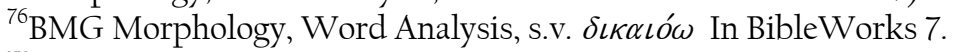

${ }^{77}$ John Murray, The Epistle to The Romans Volume I (Grand Rapids, Michigan: Wm. B. Eerdmans Publishing Co., 1964), 222.

${ }^{78}$ Dave Hagelberg, Tafsiran Roma dari Bahasa Yunani (Bandung: Kalam Hidup, 2013), 130.
} 
seharusnya dapat mendorong seseorang untuk hidup sesuai dengan imannya. Tidak mau lagi diperhamba oleh dosa dan tidak mau lagi mengikuti tuntutan keinginannya.

\section{Hidup Bersama Kristus (6:8-9)}

Ayat 8 , "Jadi jika kita telah mati dengan Kristus, kita percaya, bahwa kita akan hidup juga dengan Dia." Pada bagian sebelumnya Paulus telah menjelaskan salah satu sisi dari persatuan dengan kematian dan kebangkitan Kristus, yaitu yang berhubungan dengan kematian orang percaya bersama Kristus. Pada bagian ini Paulus menjelaskan sisi yang lain lagi, yaitu yang berhubungan dengan kebangkitan orang percaya bersama Kristus. Kata pisteuomen yang berarti "kita percaya" menunjukkan aspek iman dalam persatuan orang percaya dengan Kristus. Orang percaya meyakini Kristus tidak tinggal dalam kematian (maut), melainkan Dia juga bangkit mengalahkan maut dan hidup. Orang percaya dapat meyakini bahwa jika ia telah mati dengan Kristus, maka pasti ia akan hidup juga dengan Dia. Kepercayaan (iman) ini dapat berdiri teguh karena disandarkan pada fakta kebangkitan Kristus.

"Kita akan hidup dengan" adalah terjemahan dari kata suzesomen yang merupakan kata kerja future indikatif aktif orang pertama jamak ${ }^{79}$ dapat juga berarti "kita akan hidup bersama" ${ }^{80}$ Bentuk future di sini tidak merujuk pada kebangkitan tubuh orang percaya pada masa akan datang, tetapi sesuai konteks merujuk kepada hidup baru yang menjadi realitasnya saat ini. Paulus hendak berkata bahwa dalam persatuan dengan kematian dan kebangkitan Kristus, orang percaya bukan hanya dihidupkan sama seperti Kristus bangkit dan hidup, tetapi lebih daripada itu, ia diberikan hidup baru yaitu hidup bersama Kristus yang bangkit. Kehidupan bersama Kristus menjadi realitas masa kini yang tampak dalam identitas baru orang percaya. ${ }^{81}$

"Hidup bersama Kristus" sebagai konsekuensi dari persekutuan orang percaya dengan Kristus dalam aion yang baru, menjadi kontras yang tajam dengan "maut" sebagai konsekuensi dari persekutuannya dengan Adam dalam aion yang lama. Dalam aion yang lama ia mengalami keterpisahan dengan Allah (maut), sedangkan dalam aion yang baru ia mengalami persekutuan kembali dengan Allah (hidup bersama Kristus).

\footnotetext{
${ }^{79} \sigma \nu \zeta \not ́ \sigma o \mu \epsilon \nu$ verb indicative future active lst person plural from suza,w (BMG Morphology, Word Analysis, s.v. $\sigma \nu \zeta \eta ́ \sigma o \mu \epsilon \nu$ In BibleWorks 7).

${ }^{80}$ Hasan Sutanto, Perjanjian Baru Interlinear Yunani-Indonesia dan Konkordansi Perjanjian Baru Jilid II (Jakarta: Lembaga Alkitab Indonesia, 2006), s.v. $\sigma u \zeta \alpha^{\prime} \omega$.

${ }^{81}$ Ryan Collman, Exegesis of Romans 6:1-14: Dead to Sin and Alive in Christ; diakses 12 Maret 2014, www.academia.edu/5682071/Romans_6_l-

14_Dead_to_sin_and_Alive_in_Christ
} 
Ayat 9, "Karena kita tahu, bahwa Kristus, sesudah Ia bangkit dari antara orang mati, tidak mati lagi: maut tidak berkuasa lagi atas Dia." Ayat ini adalah penegasan dari kebenaran yang dinyatakan dalam ayat 8 . Kehidupan orang percaya bersama Kristus adalah realitas masa kini dan berlangsung terus sepanjang hidupnya, bahkan sampai kebangkitan tubuhnya dan berlanjut dalam kekekalan. Semuanya dapat terjadi karena Kristus, sesudah Ia bangkit dari antara orang mati, tidak mati lagi. Dengan kata lain, Ia hidup dan terus hidup.

Kata "berkuasa" yang diterjemahkan dari kata kurieuei menggambarkan maut sebagai tuan atau penguasa. Dalam kebangkitan Kristus terjadi peralihan kekuasaan, Kristus beralih dari dikuasai oleh maut menjadi penguasa atas maut. ${ }^{82}$ Maut bukan hanya tidak berkuasa lagi atas Dia, tetapi justru oleh kebangkitan Kristus, maut takluk di bawah kekuasaan Kristus.

\section{Hidup Bagi Allah (6:10-11)}

Ayat 10, "Sebab kematian-Nya adalah kematian terhadap dosa, satu kali dan untuk selama-lamanya, dan kehidupan-Nya adalah kehidupan bagi Allah." Pemakaian kata "sebab" menunjukkan bahwa ayat ini pun bertujuan untuk menjelaskan ayat sebelumnya (ayat 9), mengapa maut tidak berkuasa lagi atas Kristus? Sebab kematian-Nya adalah kematian terhadap dosa. Frasa $\tau \hat{\eta} \hat{\alpha} \mu \alpha \rho \tau i ́ \alpha$ adalah kata benda dalam bentuk datif kerugian (incommodi) ${ }^{83}$ yang sama dengan ayat 2. Di sini Kematian Kristus terhadap dosa bukanlah kematian untuk kepentingan atau untuk penebusan dosa, tetapi kematian Kristus terhadap dosa yang berperan sebagai penguasa (otoritas yang berkuasa dan menuntut). ${ }^{84}$ Dosa hanya bisa diselesaikan melalui maut, sebab upah dosa adalah maut (Rm. 6:23). Karena itu selama maut belum terjadi, dosa akan berkuasa dan terus menuntut. Kematian Kristus bertujuan untuk memenuhi tuntutan (upah) dosa itu, satu kali dan untuk selama-lamanya, sehingga dosa tidak berkuasa lagi untuk menuntut. Jadi kematian Kristus telah menghancurkan kuasa dosa. Dan karena Kristus dibangkitkan oleh kemuliaan Bapa (ayat 4), maka kehidupan-Nya adalah kehidupan bagi Allah.

Ayat 1l, "Demikianlah hendaknya kamu memandangnya: bahwa kamu telah mati bagi dosa, tetapi kamu hidup bagi Allah dalam Kristus Yesus." Ayat ini adalah terjemahan dari (houtos kai humeis logizesthe heautous [einai] nekrous men te hamartia zontas de to theo en Christo Yesou. ${ }^{85}$ Jika

\footnotetext{
${ }^{82} \mathrm{Ibid}$.

${ }^{83}$ Herman Ridderbos, Paulus: Pemikiran Utama Theologinya (Surabaya: Momentum,

${ }^{84}$ Ibid.

${ }^{85}$ BGT Version, BibleWorks Greek LXX/BNT In BibleWorks 7.
} 2010), 217. 
diterjemahkan secara harfiah menjadi, "Demikian juga kamu anggaplah ${ }^{86}$ dirimu sendiri (adalah) ${ }^{87}$ sungguh-sungguh ${ }^{88}$ mati bagi dosa tetapi hidup bagi Allah dalam Kristus Yesus."

Kata "anggaplah" (TB: memandang) dalam konteks ini, sesungguhnya melibatkan kesadaran dan keyakinan iman. Penggunaan kata-kata "demikian juga" di awal ayat ini memberikan dasar mengapa harus menganggap atau memandang. Dasar itu merujuk ke ayat sebelumnya, yaitu kematian Kristus adalah kematian terhadap dosa dan kehidupan-Nya adalah kehidupan bagi Allah (ayat 10). Ini jugalah dasar dari kesadaran dan keyakinan iman orang percaya bahwa ia mati bagi dosa, tetapi hidup bagi Allah. Kata logizesthe juga adalah kata kerja present imperatif ${ }^{89}$ yang berarti suatu perintah untuk terus menerus menganggap atau memandang diri sendiri mati bagi dosa, tetapi hidup bagi Allah.

"Hidup bagi Allah" berarti seluruh hidup untuk kepentingan Allah atau untuk menyenangkan Allah. Seseorang bisa hidup menyenangkan Allah hanya jika ia hidup sesuai dengan kehendak Allah. Dengan kata lain, ia hidup untuk menggenapi rencana dan rancangan Allah bagi dirinya.

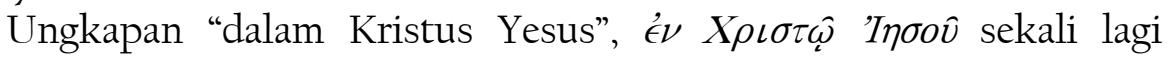
mengungkapkan persatuan orang percaya dengan Yesus Kristus. Seperti yang telah dinyatakan dalam ayat 3 , persatuan ini ia peroleh melalui baptisan. Ungkapan ini menyatakan bahwa ia hanya bisa berbagian dengan karya Kristus dan menikmati semua konsekuensinya, yaitu kematian, kebangkitan, dan kehidupan-Nya, jika ia telah dipersatukan dengan kematian dan kebangkitan Kristus.

\section{Realisasi Hasil Persatuan dengan Kristus (6:12-13)}

\section{Menolak Dosa (6:12)}

"Sebab itu hendaklah dosa jangan berkuasa lagi di dalam tubuhmu yang fana, supaya kamu jangan lagi menuruti keinginannya." Terjemahan dari me oun basileueto he hamartia en to thneto humon somati eis to hupakouein tais

\footnotetext{
${ }^{86}$ Kata perintah atau permintaan, diterjemahkan dari kata logi,zesqe yang berasal

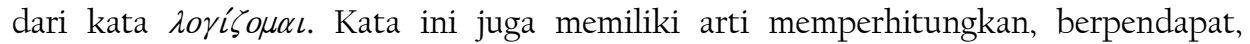
menyadari. Hasan Sutanto, Perjanjian Baru Interlinear Yunani-Indonesia dan Konkordansi

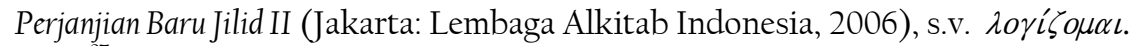

${ }^{87}$ Kata kerja present infinitif aktif dari $\epsilon i \mu i$ (BMG Morphology, Word Analysis, s.v. $\epsilon i \nu \alpha \iota$ In BibleWorks 7).

${ }^{88}$ Partikel penegasan dari $\mu \dot{\epsilon} \nu$ (BMG Morphology, Word Analysis, s.v. $\mu \dot{\epsilon} \nu$ In BibleWorks 7).

${ }^{89} \lambda o \gamma i \zeta \epsilon \sigma \theta \epsilon$ verb imperative present middle 2nd person plural from logi,zomai

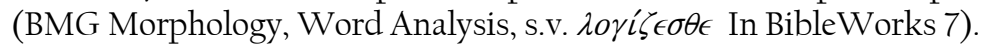


epithumiais autou. ${ }^{90}$ Kata perintah $\beta \alpha \sigma \iota \lambda \epsilon v e ́ t \omega \omega^{91}$ yang digabungkan dengan $\mu \dot{\eta}$ menyatakan suatu penolakan yang keras, "jangan berkuasa lagi". Dalam hal ini, dosa yang digambarkan sebagai penguasa tidak boleh lagi berkuasa dalam tubuh yang fana. "Tubuh yang fana" adalah keseluruhan diri seseorang yang ia hidupi saat ini yang penuh dengan keterbatasan dan kelemahan. Sesungguhnya orang percaya tidak lagi berada di bawah kekuasaan dosa, karena ia telah beralih kepada penguasa yang lain, yaitu Kristus. Sekalipun demikian, dosa masih terus berusaha untuk merebut kembali kekuasaannya dan tubuh yang fana masih bisa tergoda untuk kembali kepada kuasa dosa. Itulah sebabnya, Paulus meminta supaya orang percaya terus menerus menolak dosa.

Orang percaya harus terus berjuang menolak dosa supaya tidak menuruti keinginan-keinginan tubuh. Keinginan tubuh selalu menjadi dasar berpijaknya dosa dalam diri seseorang (bnd. Yak. 1:14-15), bahkan dosa membangkitkan rupa-rupa keinginan (Rm. 7:8). Ketika dosa menguasai tubuh, maka seseorang tidak berdaya untuk menolak keinginan-keinginannya. Sebaliknya, jika Kristus yang berkuasa maka ia juga dapat menolak keinginan tubuh dan menaati keinginan Kristus.

\section{Tidak Menyerahkan Anggota Tubuh Kepada Dosa (6:13a)}

"Dan janganlah kamu menyerahkan anggota-anggota tubuhmu kepada dosa untuk dipakai sebagai senjata kelaliman." Kalimat "dan janganlah kamu menyerahkan..." diterjemahkan dari kata paristanete ${ }^{92}$ yang merupakan kata present imperatif (kata perintah) dan digabungkan dengan partikel mede yang berarti "dan jangan". ${ }^{93}$ Jadi $\mu \eta \delta \dot{\epsilon}$

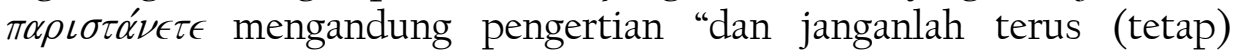
menyerahkan..." Di sini Paulus menggunakan "anggota-anggota tubuh" yang dimaksudkan adalah semua bagian dari tubuh tanpa terkecuali, berbeda dengan ayat 12 yang menjelaskan tentang tubuh secara keseluruhan.

Dosa memang menggunakan anggota-anggota tubuh untuk dapat memanifestasikan dirinya. Paulus memerintahkan kita untuk jangan terus menyerahkan anggota-anggota tubuh kepada dosa untuk dipakai sebagai senjata kelaliman. "Senjata kelaliman" diterjemahkan dari hopla adikias. Kata ö $\pi \lambda \alpha$ berarti senjata, ${ }^{94}$ sedangkan kata $\alpha \dot{\delta} \delta \kappa i ́ \alpha \varsigma$ berarti

\footnotetext{
${ }^{90}$ BGT Version, BibleWorks Greek LXX/BNT In BibleWorks 7.

${ }^{91} \beta \alpha \sigma \iota \lambda \epsilon \nu \in \epsilon \tau \omega$ verb imperative present active 3rd person singular from $\beta \alpha \sigma \iota \lambda \epsilon u ́ \omega$ (BMG Morphology, Word Analysis, s.v. $\beta \alpha \sigma \iota \lambda \epsilon u \epsilon ́ \tau \omega$ In BibleWorks 7).

${ }^{92} \pi \alpha \rho \iota \sigma \tau \alpha \dot{\nu} \epsilon \tau \epsilon$ verb imperative present active 2nd person plural from pari,sthmi

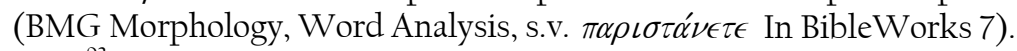

${ }^{93} \mathrm{BMG}$ Morphology, Word Analysis, s.v. $\mu \eta \delta \epsilon$ In BibleWorks 7.

${ }^{94}$ BMG Morphology, Word Analysis, s.v. ö $\pi \lambda \alpha$ In BibleWorks 7.
} 
ketidakbenaran dari hati dan hidup ${ }^{95}$ (moral dan perbuatan). Pengertian ini menjelaskan bahwa anggota-anggota tubuh dapat dipakai oleh dosa sebagai alat yang aktif (senjata) untuk melakukan segala ketidakbenaran (kelaliman). Orang percaya tidak pernah diizinkan untuk melakukan hal yang demikian.

\section{Serahkan Diri kepada Allah (6:13b)}

"Tetapi serahkanlah dirimu kepada Allah sebagai orang-orang, yang dahulu mati, tetapi yang sekarang hidup." Kalimat, "serahkanlah dirimu kepada Allah" adalah terjemahan dari parastesate heautous to theo. ${ }^{96}$ Kata $\pi \alpha \rho \alpha \sigma \tau \dot{\eta} \sigma \alpha \tau \epsilon$ adalah kata aorist imperatif ${ }^{97}$ yang berarti satu kali menyerahkan diri kepada Allah. Sebagaimana yang sudah dijelaskan sebelumnya bahwa dosa bukan lagi tuan bagi orang percaya, tetapi Kristuslah yang menjadi tuannya. Serahkanlah dirimu kepada Allah berarti jadikanlah Kristus sebagai Tuanmu, biarkan Dia yang memerintah dalam kehidupanmu dan siaplah untuk mengabdi kepadaNya.

Sebagai orang-orang yang dahulu mati tetapi yang sekarang hidup. "Orang yang dahulu mati" merujuk kepada orang yang telah dipersatukan dengan kematian Kristus (mati bersama Kristus) yang berarti telah bebas dari kekuasaan dosa. "Yang sekarang hidup" merujuk kepada orang yang telah dipersatukan dengan kebangkitan Kristus (bangkit bersama Kristus) yang berarti hidup dalam kehidupan yang baru. Tampak jelas titik balik kehidupan orang percaya melalui persatuannya dengan kematian dan kebangkitan Kristus. Sebelumnya di bawah kuasa dosa yang berakibat maut, sekarang menjadi di bawah kuasa Kristus yang berakibat hidup yang baru.

\section{Serahkan Anggota Tubuh kepada Allah (6:13c)}

"Dan serahkanlah anggota-anggota tubuhmu kepada Allah untuk menjadi senjata-senjata kebenaran." Ini adalah kebalikan dari pernyataan dalam ayat 13a, jangan menyerahkan anggota-anggota tubuh kepada dosa untuk dipakai sebagai senjata kelaliman, sebaliknya, serahkanlah kepada Allah untuk dipakai sebagai senjata-senjata kebenaran. Kata "kebenaran"

\footnotetext{
${ }^{95}$ Thayer's Greek Definitions, s. v. $\dot{\alpha} \delta \iota \kappa i a$ In e-Sword - the Sword of the Lord with an electronic edge.

${ }^{96}$ BGT Version, BibleWorks Greek LXX/BNT In BibleWorks 7.

${ }^{97} \pi \alpha \rho \alpha \sigma \tau \eta \dot{\sigma} \sigma \tau \tau$ verb imperative aorist active 2 nd person plural from pari,sthmi

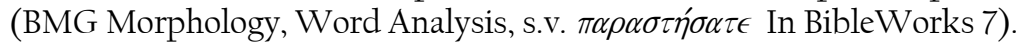


diterjemahkan dari kata dikaiosunes berasal kata dikaiosune ${ }^{98}$ yang merupakan antonim dari kata adikia. ${ }^{99}$

Allah juga memakai anggota-anggota tubuh untuk dipakai sebagai alat yang aktif (senjata untuk menyerang ketidakbenaran) untuk melakukan kebenaran. Inilah bentuk pengabdian diri orang percaya kepada Tuannya yang baru, yaitu Kristus, Tuhan. Ia merelakan seluruh anggota tubuhnya kepada Allah untuk dipakai-Nya melakukan kebenaran bagi kemuliaan-Nya. Kristus bangkit oleh kemuliaan Allah untuk hidup bagi Allah, demikian juga, orang percaya hidup oleh anugerah Allah, bagi Allah, untuk kemuliaan-Nya. "Sebab segala sesuatu adalah dari Dia, dan oleh Dia, dan kepada Dia: Bagi Dialah kemuliaan sampai selama-lamanya!" (Rm. 11:36).

\section{Kesimpulan (6:14)}

"Sebab kamu tidak akan dikuasai lagi oleh dosa, karena kamu tidak berada di bawah hukum Taurat, tetapi di bawah kasih karunia." Ini adalah kesimpulan yang sebenarnya tidak hanya merangkum nas ini (Rm. 6:1-13), melainkan merangkum secara keseluruhan pasal 5 dan 6. Dalam pasal 5 telah dinyatakan tentang perlunya iman untuk menerima kasih karunia Allah (Rm. 5:2) dan juga tentang hukum Taurat yang memperbanyak pelanggaran (dosa), tetapi kasih karunia juga berlimpahlimpah dan sanggup mengatasinya (Rm. 5:20-21). Kasih karunia itu adalah orang percaya dipersatukan dengan kematian dan kebangkitan Kristus (Rm. 6:1-13), sehingga ketaatan Kristus menjadi kebenaran orang percaya (Rm. 5:19). Kemudian bertolak dari ayat ini Paulus menguraikan bagian kedua dari pasal 6.

Bentuk future dari kata kurieusei ${ }^{100}$ yang berarti "menguasai" sebaiknya dimaknai sebagai sesuatu yang secara logis seharusnya terjadi pada diri orang percaya menyusul persatuannya dengan kematian dan kebangkitan Kristus. Dosa tetap dalam pengertian penguasa. Jadi, "dosa tidak akan menguasai kamu," bukanlah jaminan bahwa ia tidak akan berbuat dosa lagi, tetapi merupakan suatu jaminan atas fakta ia telah mati bagi dosa. ${ }^{101}$

"Tidak berada di bawah hukum Taurat," harus dipahami dalam pengertian bahwa hukum Taurat adalah alat dosa untuk menciptakan

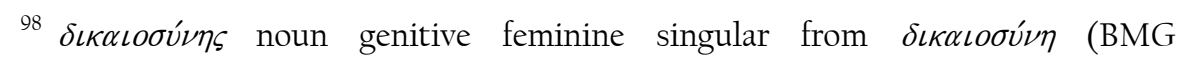

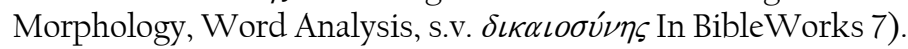

${ }^{99}$ The Complete Word Study Dictionary (AMG International, Inc. in e-Sword - the

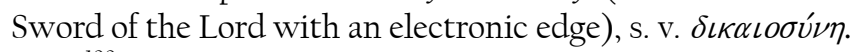

$100 \kappa \nu \rho \iota \epsilon \dot{\sigma} \epsilon \iota$ verb indicative future active 3rd person singular from kurieu,w (BMG

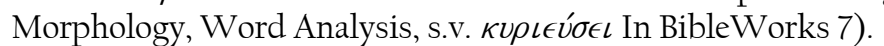

${ }^{101}$ John Murray, The Epistle to The Romans Volume I (Grand Rapids, Michigan: Wm. B. Eerdmans Publishing Co., 1964), 228. 
lebih banyak pelanggaran dalam diri seseorang (Rm. 7:8). Sebab salah satu fungsi hukum Taurat adalah untuk memperkenalkan dosa (Rm. 3:20). Orang percaya telah mati bagi dosa, karena itu dosa tidak dapat lagi memperhamba dia melalui hukum Taurat untuk menciptakan dosa dalam dirinya (Rm. 6:16-17). Itulah artinya tidak berada di bawah hukum Taurat.

"Di bawah kasih karunia," mengingatkan orang percaya pada karya Yesus Kristus. Kristus telah mewakili manusia dalam ketaatan sehingga semua orang menjadi orang benar (Rm. 5:19). Orang percaya dapat menikmati hasil dari karya Kristus melalui persatuannya dengan Kristus. Inilah kasih karunia. Bahkan kasih karunia memberikan kepada orang percaya kehidupan yang baru, kehidupan bersama Kristus yang memampukannya untuk menaati hukum Taurat dengan kerelaannya sendiri.

\section{Implementasi Konsep Persatuan Dengan Kematian dan Kebangkitan Kristus Dalam Kehidupan Orang Percaya}

Konsep persatuan dengan Kristus merupakan kebenaran yang fundamental dan hakiki dalam kekristenan. John Murray mengatakan, "Persatuan dengan Kristus merupakan kebenaran sentral dari seluruh doktrin keselamatan." ${ }^{102}$ Iman dan pengharapan orang percaya dibangun di atas kebenaran ini. Semua pengalaman dan berkat rohani orang percaya hanya bisa diterima, dialami dan menjadi kenyataan di dalam kehidupan sehari-hari, jika ia telah dipersatukan dengan Kristus dan berada di dalam Kristus. Melalui persatuan dengan Kristus, semua yang adalah milik Kristus menjadi milik orang percaya melalui iman. ${ }^{103}$ Mengabaikan kebenaran ini berarti kehilangan berkat-berkatnya yang adalah sumber kekuatan bagi orang percaya untuk menjalani hidup kekristenan. Berikut ini adalah beberapa kebenaran dari konsep persatuan dengan kematian dan kebangkitan Kristus yang dapat diimplementasikan atau diterapkan dalam kehidupan orang percaya.

\section{Orang Percaya Telah Dipersatukan dengan Kristus}

Orang percaya adalah orang yang telah dipersatukan dengan kematian dan kebangkitan Kristus. Persatuan ini diperolehnya melalui baptisan. Sekalipun dalam nas Roma 6:1-14, Paulus merujuk kepada baptisan Kristen (baptisan air), tetapi yang dia maksudkan

102 John Murray, Redemption Accomplished and Applied (Grand Rapids, Mich: Eerdmans, 1955), 170. Dikutip oleh James Montgomery Boice, Dasar-Dasar Iman Kristen (Surabaya: Momentum, 2011), 441.

${ }^{103}$ Sinclair B. Ferguson, Kehidupan Kristen: Sebuah Pengantar Doktrinal (Surabaya: Momentum, 2011), 146. 
sesungguhnya adalah pengalaman awal seseorang menerima keselamatan. Pengalaman yang di dalamnya seseorang mengalami kelahiran kembali oleh karya Roh Kudus, sehingga ia dapat memiliki iman kepada Kristus. Paulus secara konsisten menekankan bahwa hanya oleh iman seseorang diselamatkan (Rm. 3:22; 5:1-2; Ef. 2:8-9). Paulus menggunakan lambang baptisan karena baptisan merupakan peneguhan dari apa yang sudah terjadi pada waktu seseorang percaya kepada Kristus, yakni penyaliban daging yang berdosa. Hal ini Paulus tegaskan dengan jelas dalam Galatia 3:26-27, "Sebab kamu semua adalah adalah anak-anak Allah karena iman di dalam Yesus Kristus. Karena kamu semua, yang dibaptis dalam Kristus, telah mengenakan Kristus." Bagi Paulus pengangkatan menjadi anak dan hal mengenakan Kristus tak dapat dipisahkan. ${ }^{104}$

Persatuan dengan Kristus merupakan persatuan yang dikerjakan oleh Roh Kudus dan karena itu, ini adalah persatuan roh. ${ }^{105}$ Kepada jemaat di Korintus, Paulus berkata, "Sebab dalam satu Roh kita semua, baik orang Yahudi, maupun orang Yunani, baik budak, maupun orang merdeka, telah dibaptis menjadi satu tubuh dan kita semua diberi minum dari satu Roh (1 Kor. 12:13). Demikian pula kepada jemaat di Roma, Paulus menyatakan, "Tetapi jika Kristus ada di dalam kamu, maka tubuh memang mati karena dosa, tetapi roh adalah kehidupan oleh karena kebenaran. Dan jika Roh Dia, yang telah membangkitkan Yesus dari antara orang mati, diam di dalam kamu, maka Ia, yang telah membangkitkan Kristus Yesus dari antara orang mati, akan menghidupkan juga tubuhmu yang fana itu oleh Roh-Nya, yang diam di dalam kamu" (Rm. 8:10-11).

Persatuan dengan Kristus bukan persatuan yang bersifat lahiriah, melainkan persatuan yang bersifat rohani antara dua roh yang tidak saling meniadakan kepribadian satu sama lain. Melalui persatuan ini, orang percaya menerima tenaga rohani yang baru di dalam dirinya. ${ }^{106}$ Jadi, persatuan dengan Kristus bukan seperti yang dipahami oleh kelompok mistik bahwa di dalam persatuan ini ada persatuan esensi, di mana kepribadian seseorang digabungkan dengan Kristus, sehingga Kristus dan orang percaya bukan dua pribadi yang terpisah. ${ }^{107}$

Orang percaya menerima persatuannya dengan Kristus hanya melalui iman. Persatuan ini bukanlah hasil pekerjaan manusia, tetapi semuanya telah dikerjakan oleh Allah. Ketika ia sungguh-sungguh

${ }^{104}$ Donald Guthrie, Teologi Perjanjian Baru 2 (Jakarta: BPK Gunung Mulia, 1995), 301.

${ }^{105}$ Millard J. Erickson, Teologi Kristen Volume Tiga (Malang: Gandum Mas, 2004), 169.

${ }^{106}$ Ibid.

${ }^{107}$ Louis Berkhof, Teologi Sistematika Volume 4: Doktrin Keselamatan (Surabaya: Momentum, 2010), 87. 
beriman kepada Kristus, menerima Yesus sebagai Tuhan dan Juruselamatnya secara pribadi, maka ia harus mengimani bahwa ia telah dipersatukan dengan kematian dan kebangkitan Kristus oleh kuasa Roh Kudus. Dalam persatuannya dengan Kristus, ia turut ambil bagian atau turut serta dalam peristiwa-peristiwa yang telah dialami oleh Kristus dalam sejarah, sekaligus ikut serta menikmati berkat-berkat dari persatuan ini. Kematian, penguburan dan kebangkitan Kristus menjadi kematian, penguburan dan kebangkitannya. Dengan kata lain, ketika Kristus mati di kayu salib, semua yang akan dipersatukan dengan Dia juga ikut mati. Secara tersirat menyatakan bila seseorang menyandarkan imannya kepada Kristus, sekaligus ia dipersatukan dengan suatu kematian yang telah terjadi. Kesatuan dalam kematian ini perlu agar ia bisa mengambil bagian dalam hidup Kristus yang telah bangkit itu. ${ }^{108}$

\section{Orang Percaya Menyadari Statusnya dalam Kristus}

Persatuan dengan kematian dan kebangkitan Kristus memberikan berkat bagi orang percaya, yaitu terbebasnya ia dari statusnya yang lama di dalam Adam dan menerima status yang baru di dalam Kristus. Paulus menegaskannya di dalam 2 Korintus 5:17, "Jadi siapa yang ada di dalam Kristus, ia adalah ciptaan baru: yang lama sudah berlalu, sesungguhnya yang baru sudah datang." Orang percaya sebagai orang yang telah dipersatukan dengan kematian dan kebangkitan Kristus telah mengalami perubahan radikal dan sangat menentukan dalam kehidupannya berkaitan dengan dosa, yaitu perubahan status dari ciptaan lama menjadi ciptaan baru. Ia mati terhadap ciptaan lama dan hidup sebagai ciptaan baru. Kesadaran orang percaya terhadap status barunya di dalam Kristus dapat menjadi salah satu senjata terkuat atau sumber kekuatan untuk berperang melawan pencobaan-pencobaan dan godaan-godaan dunia dan daging. ${ }^{189}$

\section{Ciptaan Lama Telah Berlalu}

Semua manusia dalam persekutuannya dengan Adam sebagai manusia pertama memiliki status sebagai ciptaan lama. Sebagai ciptaan lama di dalam Adam, manusia ikut serta dalam perbuatan dosa Adam dan juga ikut serta menerima akibatnya. Oleh sebab itu, ia hidup di bawah perbudakan dosa dan akibatnya adalah maut. Ia tidak berdaya untuk melawan dosa karena ia harus tunduk kepada dosa sebagai penguasa hidupnya. Itulah keberadaan manusia dalam statusnya sebagai ciptaan lama, yaitu manusia lama.

\footnotetext{
${ }^{108}$ Donald Guthrie, Teologi Perjanjian Baru 2 (Jakarta: BPK Gunung Mulia, 1995), 300.

${ }^{109}$ Sinclair B. Ferguson, Kehidupan Kristen: Sebuah Pengantar Doktrinal (Surabaya: Momentum, 2011), 149.
} 
Sedangkan Kristus sebagai Adam kedua mewakili manusia dalam kebenaran. Kematian Kristus yang merupakan kematian terhadap dosa dipandang lebih dari sekedar kematian Yesus yang manusiawi. Paulus melihat kematian Yesus sebagai kematian ciptaan lama yang dikuasai oleh kekuatan-kekuatan jahat. ${ }^{110}$ Melalui persatuan dengan kematian Kristus, orang percaya sebagai ciptaan lama juga mengalami kematian. Statusnya yang lama, yaitu manusia lama yang telah kehilangan kemuliaan Allah (Rm. 3:23) telah disalibkan bersama dengan Kristus dan sungguh-sungguh telah mengalami kematian.

Sebagaimana Kristus mati bagi dosa, orang percaya juga telah mati bagi dosa. Akibatnya penguasaan dosa terhadap dirinya telah berakhir. Tubuh dosa yang dulunya berada di bawah kuasa dosa dan diperalat oleh dosa sebagai budaknya, sekarang telah dibuat tidak berdaya atau tidak berkuasa lagi. Status dan kuasanya telah dihancurkan dalam hidup orang percaya. ${ }^{111}$ Ini adalah kebenaran yang membebaskan orang percaya, ia tidak perlu lagi secara sukarela tunduk kepada dosa, karena dosa bukan lagi penguasa hidupnya. Inilah artinya orang percaya telah mati terhadap dosa. Ia tidak dapat hidup bertekun dalam dosa, karena itu tidak sesuai lagi dengan jati dirinya atau identitasnya sekarang sebagai orang yang telah mati bagi dosa. Bukan berarti ia telah bebas dari dosa dan tidak dapat berbuat dosa lagi. Dosa masih senantiasa menggodanya dan bisa membuatnya jatuh ke dalam dosa, namun kini ia memiliki kekuatan untuk menolaknya. Kekuatan yang diperolehnya dari Penguasa hidupnya yang baru, yaitu Kristus.

\section{Ciptaan Baru Sudah Datang}

Setelah mengalami kematian bersama dengan Kristus, orang percaya juga ikut serta mengalami kebangkitan bersama dengan Kristus. Melalui persatuan dengan kebangkitan Kristus, orang percaya menerima status sebagai ciptaan baru, yaitu manusia baru. Dalam statusnya sebagai manusia baru, orang percaya mengalami peralihan kekuasaan dalam hidupnya. Dulunya hamba dosa, sekarang ia adalah hamba Kristus. Artinya Kristus adalah Penguasa hidupnya sekarang dan karena itu, ia harus tunduk kepada Kristus.

Sebagai manusia baru, orang percaya memiliki kehidupan yang baru. Kehidupan yang baru itu adalah hidup bersama Kristus. Hidup baru orang percaya adalah hidup baru yang keluar dari kubur bersama Kristus, naik ke surga bersama Dia, tersembunyi bersama dengan Kristus di dalam Allah dan pada akhirnya menyatakan diri bersama dengan Dia

\footnotetext{
${ }^{110}$ Donald Guthrie, Teologi Perjanjian Baru 2 (Jakarta: BPK Gunung Mulia, 1995), 301.

${ }^{111}$ Sinclair B. Ferguson, Kehidupan Kristen: Sebuah Pengantar Doktrinal (Surabaya: Momentum, 2011), 182.
} 
dalam kemuliaan pada saat parousia (lihat Kol. 3:1-4). ${ }^{112}$ Orang percaya tidak hidup sendirian, melainkan hidup bersama Kristus yang bangkit, "Aku telah disalibkan dengan Kristus; namun aku hidup, tetapi bukan lagi aku sendiri yang hidup, melainkan Kristus yang hidup di dalam aku" (Gal. 2:20). Kehidupan bersama Kristus adalah realitas saat ini yang akan memampukan orang percaya untuk hidup berkemenangan atas dosa.

Kehidupan baru orang percaya memiliki tujuan, yaitu hidup bagi Allah, sama seperti Kristus bangkit dan hidup bagi Allah (Rm. 6:10). Hidup bagi Allah berarti hidup untuk kepentingan Allah. Orang percaya diselamatkan untuk melayani Allah. "Karena kita ini buatan Allah, diciptakan dalam Kristus Yesus untuk melakukan pekerjaan baik, yang dipersiapkan Allah sebelumnya. Ia mau, supaya kita hidup di dalamnya" (Ef. 2:10). Dalam segala hal orang percaya siap tunduk kepada kehendak dan rencana Allah hanya untuk kemuliaan Allah.

\section{Orang Percaya Hidup dalam Pengudusan}

Orang percaya telah mati sebagai ciptaan lama dan sekarang hidup sebagai ciptaan baru. Kematian orang percaya sebagai ciptaan lama, yang dalam konteks Roma pasal 6 disebut kematian manusia lama (manusia lama telah turut disalibkan), tidak berarti orang percaya secara otomatis sama sekali bebas dari dosa. Kematian manusia lama adalah kematian secara status dan ini merupakan pengudusan posisional yang dikerjakan oleh Kristus di salib satu kali untuk selama-lamanya. ${ }^{113}$ Status orang percaya di hadapan Allah adalah sempurna dan kudus karena telah dibenarkan berdasarkan karya Kristus yang membenarkan orang berdosa.

Paulus menyatakan dengan jelas status orang-orang percaya di dalam jemaat Korintus, "Tetapi kamu telah memberi dirimu disucikan, kamu telah dikuduskan, kamu telah dibenarkan dalam nama Tuhan Yesus Kristus dan dalam Roh Allah kita" (1 Kor. 6:11). Urutan "dikuduskan, dibenarkan" merefleksikan suatu kebenaran yang luar biasa dalam teologi Paulus, yaitu pemahaman di mana pengudusan bukan hanya terjadi setelah pembenaran, tetapi sebelumnya. Pengudusan telah terjadi sejak awal pengalaman Kristen. ${ }^{114}$

${ }^{112}$ Herman Ridderbos, Paulus: Pemikiran Utama Theologinya (Surabaya: Momentum, 2010), 221.

${ }^{113}$ Bob Utley, "Surat Paulus kepada: Jemaat di Roma" (Kumpulan Komentari Panduan Belajar Perjanjian Baru, vol. 5. Bible Lesson International, Marshall, Texas, 2010), diakses 1 Februari 2013, http://www.freebiblecommentary.org/pdf/ind/VOL05_indonesian.pdf

${ }^{114}$ Sinclair B. Ferguson, Kehidupan Kristen: Sebuah Pengantar Doktrinal (Surabaya: Momentum, 2011), 176. 
Secara status orang percaya adalah kudus, namun natur lama masih tetap ada dalam dirinya. Sesungguhnya ketika orang percaya pertama kali memercayai Yesus sebagai Juruselamat, ia tidak banyak berubah dalam kecenderungan-kecenderungan, karakter dan perilaku alamiahnya. ${ }^{115}$ Dalam kenyataan hidupnya yang sesungguhnya, orang percaya masih berdosa dan jauh dari kesempurnaan yang dinyatakan dalam statusnya. Itulah sebabnya, Paulus setelah menjelaskan tentang status orang percaya yang telah dipersatukan dengan Kristus (Rm. 6:111), memberikan serangkaian perintah untuk menjalani hidup sesuai dengan statusnya itu (Rm. 6:12-13). Perintah-perintah ini bertujuan agar orang percaya dapat merealisasikan apa yang dinyatakan oleh statusnya sebagai ciptaan baru dalam kehidupannya saat ini.

Proses menjalani hidup untuk merealisasikan atau mewujudnyatakan status sebagai ciptaan baru dalam diri orang percaya inilah yang dimaksud dengan pengudusan hidup. Pengudusan sesungguhnya merupakan karya Roh Kudus di dalam kehidupan orang percaya yang mendeskripsikan dua bidang dasar dari pertumbuhan. Pertama, pengudusan menjelaskan tentang dipisahkannya orang percaya bagi Allah dan tujuan-tujuan-Nya. Kedua, pengudusan menjelaskan tentang perilaku atau moralitas orang percaya yang menyenangkan Allah dan semakin menjadi serupa dengan Kristus. ${ }^{116}$ Yang pertama menggambarkan tentang hidup untuk melayani Allah, sedangkan yang kedua menggambarkan hidup dalam pertobatan.

\section{Hidup dalam Pertobatan}

Hidup dalam pertobatan merupakan pengudusan hidup dalam hal perilaku atau moralitas orang percaya yang menyenangkan Allah dan menuju keserupaan dengan Kristus. Paulus menjelaskan hidup dalam pertobatan melalui Roma 6:12-13a, "Sebab itu hendaklah dosa jangan berkuasa lagi di dalam tubuhmu yang fana, supaya kamu jangan lagi menuruti keinginannya. Dan janganlah kamu menyerahkan anggotaanggota tubuhmu kepada dosa untuk dipakai sebagai senjata kelaliman,..." Sekalipun orang percaya telah dipersatukan dengan Kristus dan telah mati bagi dosa, dosa tetap merupakan realitas bagi orang percaya. Statusnyalah yang berubah, bukan kehadirannya.

Paulus mendeskripsikan keadaan dan perbuatan-perbuatan dari manusia lama yang harus ditinggalkan oleh orang percaya dalam suratnya kepada jemaat di Efesus dan Kolose. Dalam surat Efesus, ia menyatakan, "Sebab itu kukatakan dan kutegaskan ini kepadamu di dalam Tuhan: Janganlah hidup lagi sama seperti orang-orang yang tidak 516.

\footnotetext{
${ }^{115}$ James Montgomery Boice, Dasar-Dasar Iman Kristen (Surabaya: Momentum, 2011),

${ }^{116}$ Ibid., 515.
} 
mengenal Allah dengan pikirannya yang sia-sia dan pengertiannya yang gelap, jauh dari hidup persekutuan dengan Allah, karena kebodohan yang ada di dalam mereka dan karena kedegilan hati mereka. Perasaan mereka telah tumpul, sehingga mereka menyerahkan diri kepada hawa nafsu dan mengerjakan dengan serakah segala macam kecemaran (Ef. 4:17-19). Sedangkan melalui surat Kolose, Paulus secara spesifik menyebutkan beberapa perbuatan manusia lama yang harus terus dimatikan oleh orang percaya, yaitu: percabulan, kenajisan, hawa nafsu, nafsu jahat, keserakahan yang sama dengan penyembahan berhala (Kol. 3:5), dan juga marah, geram, kejahatan, fitnah dan kata-kata kotor (Kol. 3:8).

Perjuangan orang percaya untuk mematikan perbuatan-perbuatan manusia lama bukanlah sesuatu yang mudah dan bisa digenapi dalam waktu singkat, tetapi bukan juga sesuatu yang mustahil untuk dicapai. Pengudusan hidup orang percaya dalam perilaku dan moralitas merupakan hasil pelaksanaan dalam praktik dari apa yang Allah kerjakan dalam diri manusia, suatu gabungan dari karya ilahi dan usaha manusia. ${ }^{117}$ Paulus menegaskan, "...kamu senantiasa taat; karena itu tetaplah kerjakan keselamatanmu dengan takut dan gentar..., karena Allahlah yang mengerjakan di dalam kamu baik kemauan maupun pekerjaan menurut kerelaan-Nya" (Flp. 2:12-13). Karena itulah, pengudusan adalah sesuatu yang memungkinkan sekalipun tidak akan mencapai kesempurnaan tanpa dosa selama hidup di dunia ini. Orang Kristen yang paling dewasa sekalipun tak akan dapat mencapai kesempurnaan tanpa dosa dalam kehidupan ini. Kesempurnaan tak akan dicapai sampai kita menjadi seperti Dia pada saat parousia. ${ }^{118}$ Kesempurnaan dalam pengudusan hanya akan tercapai kelak saat orang percaya bertemu dengan Kristus dalam kemuliaan-Nya. Guthrie mengatakan, "Paulus menganggap pengudusan sebagai suatu proses yang hanya mencapai puncaknya tatkala orang percaya tampil tak bercacat di hadapan Allah: jadi pengudusan itu mempunyai acuan ke masa kini maupun ke masa depan."1

\section{Hidup untuk Melayani Allah}

Orang percaya menjalani hidup yang sesuai dengan statusnya di dalam Kristus, jika ia hidup untuk melayani Allah. Ini adalah aspek lain dari pengudusan yang menjelaskan tentang dipisahkannya orang percaya bagi Allah dan tujuan-tujuan-Nya. Orang percaya sebagai ciptaan baru di dalam Kristus memiliki kehidupan yang baru, yaitu kehidupan bagi

\footnotetext{
${ }^{117}$ Donald Guthrie, Teologi Perjanjian Baru 2 (Jakarta: BPK Gunung Mulia, 1995), 325.

${ }^{118}$ George Eldon Ladd, Teologi Perjanjian Baru Jilid 2 (Bandung: Kalam Hidup, 1999), 435.

${ }^{119}$ Ibid., 330.
} 
Allah. Kehidupan bagi Allah adalah kehidupan yang didedikasikan untuk melayani Allah dan tujuan-tujuan-Nya. Keselamatan bukan hanya hak istimewa yang dapat dinikmati oleh orang percaya, melainkan di dalamnya termuat suatu tanggung jawab, yaitu tanggung jawab terhadap Allah. ${ }^{120}$ Paulus menekankan hal ini lewat perintah yang ia berikan, “...tetapi serahkanlah dirimu kepada Allah sebagai orang-orang, yang dahulu mati, tetapi yang sekarang hidup. Dan serahkanlah anggotaanggota tubuhmu kepada Allah untuk menjadi senjata-senjata kebenaran" (Rm. 6:13).

Menyerahkan diri kepada Allah berbicara tentang pengakuan orang percaya terhadap Allah sebagai Penguasa hidupnya. Setelah ia dibebaskan dari dosa sebagai penguasa, orang percaya tidak boleh menjadi tuan atas dirinya sendiri, tetapi Kristuslah yang sekarang menjadi Penguasa atas dirinya. Dahulu ia adalah budak dosa, namun sekarang ia adalah hamba Allah. Sebagai hamba Allah, ia harus tunduk pada kehendak Allah, mempersembahkan diri kepada Allah dan hidup untuk melayani Allah. Paulus memberi nasihat, "Karena itu, saudarasaudara, demi kemurahan Allah aku menasihatkan kamu, supaya kamu mempersembahkan tubuhmu sebagai persembahan yang hidup, yang kudus dan yang berkenan kepada Allah: itu adalah ibadahmu yang sejati” (Rm. 12:1).

\section{Kesimpulan}

Konsep persatuan dengan kematian dan kebangkitan Kristus berdasarkan Roma 6:1-14 diperoleh kesimpulan sebagai berikut:.

Pertama, orang percaya telah dipersatukan dengan kematian dan kebangkitan Kristus melalui baptisan, yang berarti ia turut serta mengalami peristiwa-peristiwa yang dialami oleh Kristus dalam sejarah, yakni penyaliban, kematian, penguburan dan kebangkitan Kristus. Kedua, persatuan dengan kematian dan kebangkitan Kristus mengakibatkan berlalunya ciptaan lama, yaitu kematian manusia lama sebagai status atau kedudukan seseorang dalam persekutuannya dengan Adam. Kematian Kristus adalah kematian bagi dosa, karena itu dalam persatuan dengan kematian Kristus, orang percaya juga telah mati bagi dosa. Ketiga, persatuan dengan kematian dan kebangkitan Kristus menghasilkan ciptaan baru, yaitu kehidupan baru sebagai status atau kedudukan orang percaya dalam persekutuan dengan Kristus. Keempat, kehidupan yang berpadanan dengan status baru orang percaya dalam Kristus adalah kehidupan dalam pengudusan yang meliputi hidup dalam pertobatan dan hidup untuk melayani Allah.

\footnotetext{
${ }^{120}$ Leon Morris, Teologi Perjanjian Baru (Malang: Gandum Mas, 2006), 45.
} 


\section{Kepustakaan}

Alkitab. Jakarta: Lembaga Alkitab Indonesia, 2004.

Berkhof, Louis. Teologi Sistematika Volume 4: Doktrin Keselamatan. Surabaya: Momentum, 2010.

Boers, Hendrikus. "The structure and meaning of Romans 6:1-14." Catholic Biblical Quarterly 63, no. 4 (October 1, 2001): 664-682.

Boice, James Montgomery. Dasar-Dasar Iman Kristen. Surabaya: Momentum, 2011.

Bruce, F. F. The Letter of Paul to The Romans: An Introduction and Commentary. Leicester: Inter-Varsity Press, 1999.

Carson, D. A et al. New Bible Commentary: $21^{\text {st }}$ Century Edition. Leicester: Inter-Varsity Press, 1995.

Collman, Ryan. "Exegesis of Romans 6:1-14: Dead to Sin and Alive in Christ." Diakses 12 Maret 2014. www.academia.edu/5682071/Romans_6_1-

14_Dead_to_sin_and_Alive_in_Christ

Constable, Thomas L. "Notes on Romans." Diakses 12 Maret 2014. http://soniclight.com/constable/notes/pdf/romans.pdf

Cranfield, C. E. B. "A Critical and Exegetical Commentary on the Epistle to the Romans (Edinburgh: T\&T Clark, 2000)."

Drewes, B. F., Wilfrid Haubeck dan Heinrich von Siebenthal. Kunci Bahasa Yunani Perjanjian Baru: Surat Roma hingga Kitab Wahyu. Jakarta: BPK Gunung Mulia, 2006.

Erickson, Millard J. Teologi Kristen Volume 3. Malang: Gandum Mas, 2004.

Ferguson, Sinclair B. Kehidupan Kristen: Sebuah Pengantar Doktrinal. Surabaya: Momentum, 2007.

Gaebelein, Frank E. The Expositors Bible Commentary Volume 10. Grand Rapids, Michigan: Zondervan Publishing House, 1976.

Guthrie, Donald. Teologi Perjanjian Baru 2. Jakarta: BPK Gunung Mulia, 1995.

Hagelberg, Dave. Tafsiran Roma dari Bahasa Yunani. Bandung: Kalam Hidup, 2013.

Harrison, Everett F. Introduction to the New Testament. Grand Rapids, Michigan: Wm. B. Eerdmans Publishing Company, 1965.

Jamieson, Robert, A. R. Fausset dan David Brown. A Commentary Critical, Experimental, and Practical Old and New Testaments. Grand Rapids, Michigan: William B. Eerdmans Publishing Company, 1990.

Ladd, George Eldon. Teologi Perjanjian Baru Jilid 2. Bandung: Kalam Hidup, 1999.

Moo, Douglas J. "Exegetical Notes Romans 6:1-14." Diakses 12 Maret 2014. http://www.djmoo.com/articles/romans6.pdf 
Moo, Douglas J. “Romans 6:1-14.” Trinity Journal 3 (September 1, 1982): 215-220.

Morris, Leon. The Epistle to the Romans. Grand Rapids, Mich.: W.B. Eerdmans, 1988.

Morris, Leon. Teologi Perjanjian Baru. Malang: Gandum Mas, 2006.

Murray, John. The Epistle to The Romans Volume I. Grand Rapids, Michigan: Wm. B. Eerdmans Publishing Co., 1964.

Newman, Barclay M. dan Eugene A. Nida. Pedoman Penafsiran Alkitab Surat Paulus kepada Jemaat di Roma. Jakarta: LAI, 2012.

Poole, Matthew. A Commentary on The Holy Bible Volume III. Mclean, Virginia: Macdonald Publishing Company, n.d.

Ridderbos, Herman. Paulus: Pemikiran Utama Theologinya. Surabaya: Momentum, 2010.

Schreiner, Thomas. Romans. Grand Rapids: Baker, 1998.

Sutanto, Hasan. Hermeneutik: Prinsip dan Metode Penafsiran Alkitab. Malang: Literatur SAAT, 2007.

Susanto, Hasan. Perjanjian Baru Interlinear Yunani-Indonesia dan Konkordansi Perjanjian Baru Jilid I dan II. Jakarta: Lembaga Alkitab Indonesia, 2006.

van den End, Th. Tafsiran Alkitab: Surat Roma. Jakarta: BPK Gunung Mulia, 2008.

Wenham, J. W. Bahasa Yunani Koine. Malang: SAAT, 1987.

Utley, Bob. "Surat Paulus kepada: Jemaat di Roma," Kumpulan Komentari Panduan Belajar Perjanjian Baru, vol. 5. Bible Lesson International, Marshall, Texas, 2010." Diakses 1 Februari 2013. http://www.freebiblecommentary.org/pdf/ind/VOL05_indonesian.p df. 